\title{
RIḌA AND ARAB CHRISTIANS: \\ ATTITUDES TOWARDS SYRIAN CHRISTIANS AND THE EGYPTIAN COPTIC COMMUNITY
}

In order to present a good picture of Ridā's relations with Arab Christians, I shall first of all describe his relations with some of his Syrian Christian fellow-citizens, who, like him, made Egypt their new residence after migration. In the course of our discussion we shall turn our focus from a short sketch of Riḍā's political ambitions with them and their struggle for independence from the colonial presence in the Arab East, towards an outline of the personal biographies of those among them with whom Riḍa had lively debates. This is suggested as a useful means of illuminating the historical context of the discussions at stake. Many of these Christian writers had championed secularism. Riḍā's attitudes towards these individuals generated very interesting discussions on religion, history, Islamic philosophy and literature. At another level, Rị̣ā's polemics with Syrians Christians was extended to include religious controversies with the Arabic Jesuit journal al-Machreq. The last part of the chapter is devoted to study his stances towards the Egyptian Copts, and his reflections as a Syrian émigré on their political demands, ending with his sharp reactions to the Christian writer Salāma Mūsā, who was a close disciple of Syrian Christian publicists in Egypt.

\subsection{Syrian Christian Nationalists: A Common Political Agenda}

The Syro-Lebanese emigrant community in Brazil knew about al-Manār right from the start of its publication. The Sao-Paulo-based journal al-Așma 'ī, co-edited by the Christians Khalīl Milūk and Shukrī al-Khūrī, reviewed al-Manār describing it as 'one of the best Islamic journals. ${ }^{\prime 1} \mathrm{Na}$ ùm al-Labaki (d. 1924), the founder of the Syrian

\footnotetext{
1 'Al-Manār fī al-Brāzīl (al-Manār in Brazil),' vol. 1/37 (Rajab 1316/December 1898), p. 734.
} 
journal al-Munāzir (The Debater) in Sao Paulo, ${ }^{2}$ blamed Riḍa for restricting the subjects of his journal to religious issues, and that he stopped his discussions on Syrian national problems and religious strife in their homeland Syria. The contents of the journal, according to him, were not in agreement with the subtitle of his journal: 'scientific, literary, informative and educating journal.' In his reply, Riḍa explained that he used to write such items before the banning of his journal in Syria, and they would have been valueless as no Syrian Muslim, Christian or Jew had access to his articles anymore. As the circle of his readers became limited to the people in Egypt, Tunisia, Algeria, Morocco, India, Java, and a group of Syrian emigrants in America, it was more appropriate for him to focus on other Islamic religious instructive issues. Riḍa was also convinced that his treatment of such Islamic themes was not only of benefit for his Muslim readers, but for Christians as well. He asserted that a Christian teacher at one of the high schools in Syria, after having read al-Manār, had ordered all previous issues. He also persuaded the director of the school to subscribe to the journal and collect its issues for the school's library. Riḍa finally concluded that it was also reasonable to subtitle his journal as 'informative and educating,' since religious sciences are the most 'venerated' fields.

Born and bred in Syria, which is known for its religious and ethnical minorities, ${ }^{3}$ Riḍa was familiar with its substantial Christian population. His coming to Egypt coincided with the resumption of the emigration wave of Syrians (most of them Christians), who fled from the Hamidian oppression to Egypt towards the end of the nineteenth century. ${ }^{4}$ In his later political career, Riḍa gathered around his political project of Arabism an active group of Syrian émigré intellectuals,

2 'Al-Manār wā al-Munāẓir,' vol. $2 / 40$ (Sha'bān 1317/December 1899), p. 683. In 1908 Labaki returned back to his birthplace Beirut, where he continued its publication. He was the president of the Representative Council of Lebanon. See, Zirikli, op. cit., vol. 8, p. 40.

3 Itamar Rabinovich, 'The Compact Minorities and the Syrian State, 1918-45,' Journal of Contemporary History 14/4, 1979, pp. 693-712. About Christian Arab Nationalism, see, Spencer Lavan, 'Four Christian Arab nationalists: A Comparative Study,' The Muslim World 57, 1967, pp. 114-125.

4 Thomas Philipp. The Syrians in Egypt 1725-1975, Stuttgart: Franz Steiner Verlag Wiesbaden GmbH, 1985, pp. 1-53. A. Hourani, 'The Syrians in Egypt in the eighteenth and nineteenth century,' in Colloque international sur l'histoire du Caire, Cairo, 1972. 
who opposed the Committee of Union and Progress (CUP) and promoted the idea of an Arab monarch. ${ }^{5}$

Political interests linked both Muslim and Christian elites in their cultural pride in Arab heritage, as a means to face the cultural expansion of the West. ${ }^{6}$ Syrian Christians, in particular, played a large role in the revival of the Arab literary movement. After his migration to Egypt, Riḍa drew closer to his Syrian Christian fellow writers and publishers. This group probably enjoyed the greatest freedom of thought that was experienced by any group of Arab intellectuals in the twentieth century. ${ }^{7}$ Most of these Syrians were Christians by origin, but adopted a strictly secularist agenda. Although the majority of those Christians enjoyed modern Western education and adopted Western methods of thinking, some of them, however, shared with Riḍa his resentment of the penetration of Western thought into the Arab world, including missionary activities. They also shared with him the same anxieties that 'the Sublime Porte would fall in the hands of Europe.'

In 1912 and 1913 new Arab political groupings came into being. One of the best known among these new groups was Hizb al-Lāmarkaziyya al-Idāriyyā al-'Uthmānī (Ottoman Administrative Decentralisation Party), which Riḍa founded in Cairo in December 1912. The party was dedicated to the achievement of self-government in the Ottoman Empire. ${ }^{9}$ Within the party, Riḍa called for an Arab revival as the necessary herald of the restoration of Islam. He also declared that as a Muslim he was a brother to all Muslims, and as an Arab a brother to all Arabs, and he saw no contradiction between the

\footnotetext{
5 Philip S. Khoury, Urban notables and Arab Nationalism: the Politics of Damascus 1860-1920, Cambridge University Press, 1983, pp. 62-63.

${ }^{6}$ See, Bruce Masters, Christians and Jews in the Ottoman Arab World: The Roots of Sectarianism, Cambridge University Press, 2004, pp. 170-182. The Christian Butrus al-Bustāni was one of the pioneers who called for Arabic cultural revival. See, Butrus Abu-Mannch, 'The Christians between Ottomanism and Syrian Nationalism: The Ideas of Butrus al-Bustani,' International Journal of Middle East Studies 11/3, 1980, pp. 287-304.

7 See, Hisham Sharabi, Arab Intellectuals and the West: the Formative years, 18751914, p. 114-121. Cf. Reeva Spector Simon et al, eds., The Origins of Arab Nationalism, Columbia University Press, 1993.

${ }^{8}$ See his articles on the Oriental Question, 'al-Mas'ala al-Sharqiyya,' al-Manār, vol. 14/11 (Dhū al-Qi'da 1329/November 1911), pp. 833-853.

9 Elie Kedourie, Arabic Political Memoirs and Other Studies, Routledge, 1974, pp. 43-44.
} 
two. ${ }^{10}$ His model of 'an Arab Empire' would have recognised both Christianity and Judaism and would have given non-Muslims the right to serve in the administration of the government and the judicial system (except the Shari ${ }^{-i} a$ courts). ${ }^{11}$

After the rise of the theory of Arabism, some Christian Arabs (mostly Syrians and Palestinians) had already implicitly accepted the theory that Islam is an essential part of Arabism because it brought grandeur to the Arabs. ${ }^{12}$ Many Arab Christians, such as Shibli Shumayyil and the prominent lawyer Iskandar 'Ammūn, had joined Riḍā's Decentralisation Party. Being on close terms with many of these Christian Syrians of his generation, Riḍa managed in his political struggle to gain the support of those who 'were unwilling to admit the inferiority of the East to the West. ${ }^{13}$ For him, Syrian Christians were 'the most advanced class in education, wealth, generosity, courage and pride. ${ }^{14}$ By 1914 he had developed to the full his theory of Arabism, which was also accepted by a group of Christian Arabs. ${ }^{15}$

The concept of the 'Greater Syria' sharpened Riḍā's desire for PanArabism. In his struggle against the imposition of the French Mandate in Syria, he played a prominent role with other Muslim, Christian and Druze nationalists. In 1918, a number of Syrian émigrés had established the Syrian-Palestinian Congress. During its first major session in Geneva (summer of 1921), where demands for Syrian unity and independence were presented to the League of Nations, Riḍa was elected as the vice-president. ${ }^{16}$ Its president Michel Luṭfallah

${ }^{10}$ Mahmoud Haddad, 'The Rise of Arab Nationalism: reconsidered,' International Journal of Middle Eastern Studies 26/2, 1994, pp. 215-216 (Quoted below, 'Rise'); Sami Zubaida, 'Islam and nationalism: continuities and contradictions,' Nations and Nationalism 10/4, 2004, pp. 407-420.

${ }^{11}$ Mahmoud Haddad, 'Arab Religious Nationalism in the Colonial Era: Rereading Rashīd Riḍā's Ideas on the Caliphate,' Journal of the American Oriental Society 117/2, 1997, pp. 270-271 (Quoted below, 'Nationalism').

12 C. Ernest Dawn, 'From Ottomanism to Arabism: The origin of an ideology,' Review of Politics 23/3, 1961, p. 396.

${ }_{13}$ Ibid.

${ }_{14}$ Al-Manār, vol. 15/1, (Muharram 1330/January 1912), p. 44.

15 Dawn, op. cit., pp. 394-395. More about Riḍā's ideas on Arabism, see, his letter to the First Arab Congress in Paris (June 1913), Al-Mu'tamar Al-'Arabì Al-'Awwal, Cairo, 1913, pp. i-iii; J. Jomier, 'Les raisons de l'adhésion du Sayyed Rashīd Riḍa au nationalisme arabe,' Bulletin de l'Institut d'Égypte 53, 1973, pp. 53-61; Adeed Dawisha, Arab Nationalism in the Twentieth Century: From Triumph to Despair, Princeton University Press, 2002, pp. 20-22.

${ }_{16}$ Marie-Renée Mouton, 'Le Congrès syrio-palestinien de Genève (1921),' Relations Internationales 19, 1979, pp. 313-328. About Riḍā's political ideas and activism, 
(1880-1961), the son of a wealthy Greek Orthodox Christian émigré in Egypt, was the inspiration behind the establishment of the Congress and its major financer. ${ }^{17}$ But by 1922, disputes between Syrian factions became intense, a rift between Syrian and Palestinian members started to appear, and the Syrian membership was split into two. Luțallah, allied with the Damascene physician Abdel-Raḥmān Shāhbandar (assassinated in 1946), chose to advocate a purely secular nationalism. The other group, headed by Shakỉb Arslān, propagated the idea of Arabism, as based on the Islamic divine tenets. They clashed with Lutfallah-Shāhbandar's faction because of their links with the British and the Hashimite royal family. Ridā chose to remain linked to the former faction, since this enabled him to concentrate on the ideological articulation of nationalism and particularly on the importance of the Islamic content in its formulation. ${ }^{18}$

\subsubsection{Faraḥ Anțūn (al-Jāmica)}

Riḍā's acquaintance with Farah Anțūn goes back to their youth in their hometown Tripoli. In their early years, he met with Anțūn for the first time at the house of Jurjī Yannī, a teacher and writer in Tripoli. At that time, Riḍā saw Anțūn as one of the most intelligent Christian young men in Syria. He was modest, shy, but eventually showed himself to be an irritable person. He often hesitated to give his opinions frankly in case he had not studied the matter in question thoroughly. ${ }^{19}$ Both young men agreed that the Syrian stage was too cramped for their dreams of entering the world of journalism. In

see, for example, Eliezer Tauber, 'Three Approaches, One Idea: Religion and State in the Thought of 'Abd al-Raḥman al-Kawākibī, Najīb 'Azūrī and Rashīd Riḍā,' British Journal of Middle Eastern Studies 21/2, 1994, pp. 190-198; id., 'Rashīd Rị̣ā and Faysal's Kingdom in Syria,' The Muslim World 85, 1995, pp. 235-245; id., 'Rashīd Riḍā as Pan-Arabist before the World War I,' The Muslim World 79/2, 1989, pp. 102-112; id., 'The Political Life of Rashīd Riḍā,' Arabist: Budapest Studies in Arabic 19-20, 1998, pp. 261-272.

17 Philip S. Khoury, Syria and the French Mandate: The Politics of Arab Nationalism 1920-1945, Princeton University Press, 1987, p. 223.

${ }^{18}$ More about the two factions, see, Philip S. Khoury, 'Factionalism among Syrian Nationalists during the French Mandate,' International Journal of Middle East Studies 13/4, 1981, pp. 441-469. Cf. Y. L. Rizq, 'A Diwan of contemporary life (305): Looking towards the Levant,' Al-Ahram Weekly, no. 449 (30 September-6 October 1999); republished in Al-Mashriq: A Quarterly Journal of Middle East Studies (Australia) 3/12, 2005, p. 59.

${ }_{19}$ Rị̣ā, Tārīkh, vol. 1, p. 805. 
1897 they decided to travel to Egypt on an Austrian ship (3 December, 1897) heading towards Alexandria together. ${ }^{20}$

During the early years of al-Manār, Riḍa entrusted Anțūn to translate French materials into Arabic. ${ }^{21}$ In Alexandria Anțūn founded his journal al-Jāmi'a (firstly appeared 1899) through which he tried to disseminate his secularist views. Rị̣a watched the progress of his friend's magazine and brought its contents on ethics, philosophy and sociology to the attention of 'Abduh, who, as a result, expressed his positive impression of Anțūn and always recommended his magazine to his friends. ${ }^{22}$

The young Christian journalist Anțūn was much influenced by the ideas of the French writer Ernest Renan, and gave the most systematic presentation of his French writings in the Arab world. He published serial translations of Renan's La Vie de Jésus. Following the path of Renan, he very soon published another article in the spring of 1902 on Ibn Rushd in which he also stressed that religious orthodoxy had obstructed the spirit of free inquiry in Islamic civilisation. ${ }^{23}$ Renan's skeptical attitude towards religion concurred perfectly with Anțūn's anticlerical feelings. ${ }^{24}$ In that article, Anțūn extended his theory to maintain that Christianity, unlike Islam, had been shown to tolerate philosophy.

Alarmed by Anțūn's arguments, Riḍā promptly raised the problem with 'Abduh, and fervently requested him to give a response. Anțūn was very surprised to learn that it was Riḍā, as one of his best friends, who agitated the feelings of the mufti against his journal. ${ }^{25}$ Ridā urgently requested 'Abduh to defend Islam and its scholars against Anțūn's 'blasphemy.' While staying in Alexandria, 'Abduh planned to meet with Anțūn to discuss the contents of his article personally,

${ }^{20}$ Ridâ̄'s diary, December, 1897. The diary of his early months in Egypt reveals that he was on close terms with Anțūn. When having visited Anțūn in the hotel in Cairo, Riḍa used, for example, to observe his prayer in the latter's room, since there was no mosque close in the neighbourhood.

${ }^{21}$ Reid, The Odyssey, p. ix.

22 Ibid. See, Tārîkh, p. 805. Cf. Riḍā's reviews of al-Jāmi'a and other works by Anțūn, al-Manār, vol. 1/48 (Shawwāl 1316/25 February 1899), p. 936; vol. 3/16 (Rabíc al-Thānī 1318/July 1900), p. 380.

${ }^{23}$ Ernest Renan, Averroes et l'Averroisme, Paris, 1852.

${ }_{24}$ About his anticlericalism, see, Reid, Odyssey, pp. 70-74.

${ }^{25}$ F. Anțūn, Ibn Rushd wā Falsafatuh, Alexandria, January 1903, p. 2 (Quoted below, Ibn Rushd). At that time, 'Abduh was traveling throughout Egyptian Northern cities to collect donations for the victims of a fire catastrophe in the Delta of Egypt. 
but had no opportunity to do so. During a tour in Northern Egypt, 'Abduh started drafting his articles of defence relying on his memory, while keeping Riḍā updated in a series of letters with the development of his investigations on the matter. He asked Riḍā to inform Anțūn of his plan to write a refutation to his article on Ibn Rushd, and to ask him whether he was ready to publish it in al-Jāmi ${ }^{\prime} a$. They agreed that Riḍa would edit the final drafts of the rejoinders in his own handwriting and send them to al-Jāmi'a for publication. Anțūn was in the beginning hesitant to give space to 'Abduh's refutation in his journal. ${ }^{26}$ But later he published most of his ideas in one separate volume supplemented with 'Abduh's response, which he dedicated to 'the fairly-minded among the Easterners, Christians, Muslims, or followers of any other religion.' 27

Their arguments did not remain purely on an intellectual level. They quickly developed into insult and distortion of each other's position, by changing the conflict into violent and contemptuous hostility. ${ }^{28}$ Riḍā and Anțūn charged each other with having escalated the problem in order to gain popularity for their journals and raise the number of subscribers. The issue also spoiled Anțūn's friendship with Rị̣a and both of them turned to accuse each other of being ignorant. Anțūn suggested that Riḍa lacked the knowledge (especially, of the French language and of the science of Kaläm) required to embark on such debates, and should have left the matter to his more erudite teacher. From his side, Riḍa maintained that his adversary had not simply made a well-intentioned mistake, but had purposely disparaged Islam as well. He also maintained that Anțūn's strategy was to separate the teacher from his disciple. Anțūn declared that while 'Abduh's rejoinders took the shape of a respectable intellectual debate, Rị̂ā was inclined to slander and offense. ${ }^{29}$

What irritated Riḍā was what he described as Anțūn's implicit intention to show up Islam as a religion that is against the spirit of science and wisdom, while Christianity was presented as the religion that promoted science in Europe. He further understood that Anțūn's ideas explicitly stressed that the nature of Islam predetermines lack of knowledge and civilisation; and that Muslims would never achieve

\footnotetext{
26 Riḍā, Tārīkh., pp. 809-810.

27 Anțūn, Ibn Rushd, p. 1.

28 Hourani, Arabic Theought, p. 254.

29 Reid, Odyssey, p. 87.
} 
progress as long as they clung to their religion and did not convert to Christianity. ${ }^{30}$

According to Riḍā, some of his readers notified him that articles like those of al-Jāmi ${ }^{\prime} a$ were more dangerous for Muslims than missionary publications. However, he maintained that Anțūn had the right to defend his religion, but should have uttered his views in a moderate way. Riḍa portrayed al-Jāmi'a as a 'sectarian' and 'religious journal' in content, although it did not overtly show any Christian tendency and still claimed itself as a platform for literary, scientific and medical subjects. ${ }^{31}$

Anțūn fervently accused Rị̣ā of having manipulated religious issues for propagating al-Manār among common Muslims. ${ }^{32}$ It was observable that al-Manār's reputation grew and witnessed a rapid increase of its circulation after Riḍa had published 'Abduh's defenses against Anțūn's work. ${ }^{33}$

Anțūn explicitly proclaimed that he never intended to take part in debating with the founder of al-Manār. By his discussion, he only endeavoured to address 'Abduh as an authoritative and a highlyesteemed Muslim scholar. In Anțūn's eyes, Riḍā, whom he had known as a 'sober' and 'restrained' person, appeared to be of a 'rash' and 'eccentric' character after having propagated insults against him. ${ }^{34} \mathrm{His}$ reaction, unlike his teacher, was 'foolish' and 'imprudent.' He was intolerant towards methods of scientific analysis and the conclusions of Al-Jāmi'a's article. In Anțūn's own words, 'the irrefutable evidence of [al-Jāmi'a] increased his [Riḍā] foolishness, and he was driven frenzied to the degree that we became anxious about his state of mind. ${ }^{35}$ He moreover compared Riḍa in his aloofness to grasp the facts mentioned in al-Jämi' $a$ in a mocking way with 'a crocodile [...] when you throw to him a pearl, he would immediately rush to smash it with his teeth, but never try to use it as an ornament to his ears. Having failed to smash the pearl, the crocodile would throw it again

30 Al-Manār, vol. $3 / 12$ (Jumāda al-Thāniya 1320/September 1902), p. 471.

${ }^{31}$ Ibid., pp. 474-475. Riḍā gave another example on how Christian magazines zealously supported Anțūn in what he saw as anti-Muslim campaign, see, al-Manār, vol. 5/13 (Rajab 1320-October 1902), pp. 515-517.

${ }^{32}$ Anțūn, Ibn Rushd, p. 6.

${ }^{33}$ See my paper, 'A Printed Muslim 'Lighthouse' in Cairo al-Manār's Early Years, Religious Aspiration and Reception (1898-1903),' Arabica: Journal of Arabic and Islamic Studies 56, 2009, pp. 27-60.

${ }^{34}$ Anțūn, Ibn Rushd, pp. 85-87, see also pp. 226-227.

${ }_{35}$ Ibid., pp. 4-5. 
and swoop down upon it while being enflamed with anger and grudge.' ${ }^{36}$

In a sixteen-page private letter addressed to 'Abduh on the pages of his magazine, Anțūn accused Riḍā of provoking the problem. His assault on al-Jāmi'a, said Anțūn, was nothing but 'envy and lack of decency.' 'Nothing,' he went further, 'would satisfy his [Riḍā's] rancour, but insulting others. ${ }^{37}$ Anțūn drew 'Abduh's attention to the fact that the 'recklessness' and 'foolishness' of his disciple would harm his position as the Grand Mufti of Egypt. ${ }^{38}$ Finally, he made three suggestions to 'Abduh: 1) to find two trustworthy arbiters among Al-Azhar scholars to judge the whole issue, 2) to disclaim all matters published in al-Manār, 3) or to bring the 'attack' of Riḍā against him and his journal to an end. In the event that Riḍa continued his campaign, Anțūn warned 'Abduh that he would instantly publish a hundred thousand copies of the letter and distribute them among the public. $^{39}$

The debate with 'Abduh undoubtedly pushed the interest in Anțūn's magazine to its highest point. But it was Riḍa's critique of al-Jāmi'a, which led to the immediate withdrawal of Muslim subscribers, which contributed to its collapse. Due to its sharp attack, al-Manār was said to be 'the assassin of al-Jāmi'a.' ${ }^{40}$ But Ridā believed that the reason for the latter's collapse was its editor's lack of knowledge of Islamic matters. After its first failure, Riḍa proudly taunted that 'no Arab paper would ever survive without its Muslim readership, as they represented the majority of the nation.' ${ }^{41}$

Al-Jāmi'a disappeared in 1904, and was revived irregularly after its editor's move to New York in the period between 1906 and 1909. We notice that Riḍā's attitude towards Anțūn started to change, and he eulogised Anțūn's efforts to republish his journal in the United States. He described it again as 'one of the best edited and most useful Arab papers. ${ }^{2} 2 \mathrm{He}$ also welcomed the return of Anțūn and his magazine

36 Ibid., p. 5.

37 As quoted in, Rị̣ā, Tārīkh, p. 812.

38 Ibid., p. 813.

39 Ibid., p. 815.

40 Ibid., p. 811. Cf. Reid, Odyssey, p. 54.

${ }^{41}$ Ibid. See also al-Manār, vol. 5/14 (Rajab 1320/October 1902), pp. 559-560; Riḍā was later informed by one of his friends that Anțūn had especially intensified his debate with 'Abduh only in order that he could gain more subscriptions. Al-Manār, vol. 5/14, pp. 559-560.

${ }^{42}$ Al-Manār, vol. 10/2 (Șafar 1325/April 1907), p. 158. 
to Egypt in $1909 .{ }^{43}$ But Anțūn only managed to publish two more issues of his journal, and it disappeared for good in the following years. ${ }^{44}$

After Anțūn's death in 1922, it was Rị̣ā who demanded a ceremony dedicated to his memory. One of Anțūn's biographers believes that by this attempt Riḍa tried to make amends for their old conflict. ${ }^{45} \mathrm{In}$ a letter (see, appendix IV), Rose Anțūn, Farah's younger sister, expressed her gratitude to Riḍa for his initiative by saying: '[since] I was staying with my brother in all his doings till the last moment of his life, I know perfectly well how he held you in very high esteem. [...] Now with all what you did, you have added one new noble deed to all the ones we knew from you before. I shall never forget it that you were the first one my eyes had grasped during the funeral ceremony and the first to summon upon my brother's commemoration. ${ }^{46}$

\subsubsection{Jurjī Zaidān (al-Hilāl)}

The Greek Orthodox Jurjī Zaidān (1861-1914) was an important member of the Syrian community in Egypt. ${ }^{47}$ In 1892 he founded his magazine al-Hiläl (The Crescent) in which he published much on ethics, sociology, geography, literature, Arab history, and world politics. He also published many works on many subjects such as the history of Lebanon, education and social order, Machiavelli and Ibn Khaldūn, and the siege of Damiette by the Crusaders. Just like many of his contemporary Syrian Christian intellectuals, Zaidān held the view that each religion is to a certain extent in agreement with the

${ }^{43}$ Al-Manār, vol. 13/2 (Șafar 1328/March 1910), p. 142.

${ }^{44}$ Reid, Odyssey, p. 42.

45 A. Abū Khị̣r Mansī, Farah Anțūn, Cairo, 1923, p. 23.

${ }^{46}$ Letter, Rose Anțūn to Riḍā, Cairo, 24 February 1923. The ceremony took place on the first of March 1923 at the American University in Cairo. Riḍa delivered a speech in which he referred to the history of his relation with Anțūn. For more details about Anțun's commemoration, see, the supplement of his sister's magazine Majallat al-Sayyidāt wā al-Rijāl, Faraḥ Anțūn: Hayātuh wā Ta'bìnuh wā Mukhtārātuh, Cairo, September 1923.

${ }^{47}$ Much has been written on him, see his memoirs, Mudhakkirāt Jūrjī Zaidān, Salāḥ al-Dīn al-Munajjid, ed., Beirut: Dār al-Kitāb al-Jadīd, 1968; Hamdi Alkhayat, Gurgi Zaidan: Leben und Werk, PhD dissertation, Cologne: Orient Mercur Verlag, 1973; Thomas Philipp, Gurgi Zaidan: His Life and Thought, Beirut, 1979 (Quoted below, Gurgi); id. 'Language, History, and Arab National Consciousness in the Thought of Jurji Zaidan (1861-1914),' International Journal of Middle East Studies 4/1, 1973, pp. 3-22; id., 'Women in the Historical Perspective of an Early Arab Modernist (Gurgi Zaidan),' Die Welt des Islams 18/1-2, 1977, pp. 65-83. 
sciences, though for him science should remain the decisive criterion in evaluating things. He was impressed by Muhammad 'Abduh and his recognition of the 'duty to interpret the Qur'ān in such a fashion as to bring it into agreement with modern science. ${ }^{48}$ As a Christian intellectual, Zaidān's writings on Islam were, as described by T. Philipp, mostly 'precarious. ${ }^{49}$ When dealing with the relationship between Islam and Christianity he tried to play down any tension between both religions, and tended to show that Christians during most of history lived in harmony with their Muslim compatriots. ${ }^{50}$

A few days after his arrival in Egypt, Riḍa met Zaidān in the company of Anțūn for the first time in the latter's office at al-Hiläl (January 1989). Their first conversation focused on the situation of journalism in Egypt. ${ }^{51}$ When Rị̣ā established himself as a Muslim journalist, Zaidān used to send al-Manār his novels on Islamic history and literature in order for Riḍā to review them critically.

In the early years of their relation, Riḍā, at many occasions, praised Zaidān as 'a historian with objective eyes' ${ }^{52}$ who appreciated others' criticism of his own views. ${ }^{53}$ While involved in his controversy with Faraḥ Anțūn, Riḍā was earnestly defending Zaidān against the criticism of some Muslims, who accused him of 'religious fanaticism' and tried to disqualify his works on Islamic history as a Christian thinker. ${ }^{54}$ Ridea, on the contrary, saw the benefit of such

${ }_{48}$ Philipp, Gurgi, pp. 58-59.

${ }^{49}$ Ibid., p. 59.

${ }^{50}$ Ibid., p. 60.

51 Riḍā's Diary (1897-1898).

52 Al-Manār, vol. 5/9 (Jumāda al-'Ūlā 1320/August 1902), pp. 356-357.

${ }_{53}$ See, for example, al-Manār, vol. 6/10 (Jumadā al-'Ülā 1321/August 1903), pp. 391-398. Riḍa also received questions from his readers as a result of their readings in Zaidān's novels on Islamic history, see, Riḍā's fatwā on reciting the Qur'ān in the graveyard raised by a student of Al-Azhar, al-Manār, vol. 5/13, p. 508.

${ }^{54}$ The first Muslim to criticise Zaidan was the traveler and book dealer Amin al-Halwāni al-Madanī. See his short book, Nabsh al-Hadhayān min Tārikh Jurjī Zaidān, Bombay, 1307/1890. It was a rejoinder to Zaidan's history of modern Egypt. In his work, Madanī enumerated 101 errors attributed to the writer. In 1891, Zaidān published his Radd Rannān 'alā Nabsh al-Hadhayān in which he alluded to al-Halwāni's Indian origin and his jealousy of the Syrian success. See, Lewis Beier Ware, 'Jurji Zaydan: The Role of Popular History in the Formation of a New Arab World-View,' PhD Dissertation, Princeton University, 1973, pp. 196-197. More about Madanī and his visit to Amsterdam and Leiden (1882-1883) and his participation in the Leiden Orientalists Congress (1883), see, C. Snouck Hurgronje, Het Leidsche Orientalistencongres: Indrukken van een Arabisch Congreslid, Leiden: E.J. Brill, 1883; about his life, Ziriklī, op. cit., vol. 2, pp. 15-16. 
novels in educating Muslim youngsters about unknown parts of their own history. He often excused Zaidān for his historical mistakes, since he, as a novelist, was allowed sometimes to collect his information on a non-historical basis. In his historical novel Fatāt Ghassān (The Maiden of Ghassān), Zaidān went further by citing the controversial Muslim narrative on the story of al-Gharāniq. Riḍa mildly criticised Zaidān for having incautiously mentioned such a controversial story. Despite his strong conviction in its forged nature, Riḍā believed that Zaidān included the story in his novel on the basis of the account of the early Muslim historiographer al-Tabarī. He maintained that 'he [Zaidān], as a Christian, should be forgiven if he believed in the story. Some early Muslim scholars mentioned it without giving any critical remarks. ${ }^{55}$ Another noteworthy example was the harsh criticism of many Muslims against Zaidān's acceptance of the story that the Prophet's regular meetings with monks (such as Bahīra) and other lettered people in his young age had an immense impact on his later religious career as a Prophet, especially during the commercial trips with his uncle. ${ }^{56}$ Although Ridā rejected Zaidān's interpretation, he was certain that he had no intention whatsoever of defaming Islam. Meanwhile he demanded that Muslims should learn only from authoritative and well-versed Muslim scholars instead of depending on such works. Despite all these critical remarks, Riḍa insisted on his appreciation of Zaidān's enrichment of Arabic literature. He never thought that the latter had any intention of offending or attacking Islam, nor was he ever proved to be 'a fanatic Christian. ${ }^{57}$

Riḍā's response to Zaidān's works on Islamic history was inconsistent. His attitude towards the man drastically changed because of their political differences. The most significant example was Ridā's approach to the latter's voluminous work on the history of Islamic civilisation..$^{58}$ When Zaidān embarked upon writing his work (1902), Rị̣a regularly praised his endeavours as a service to Muslims and Arabs by compiling in one piece of work their history which was scattered through the various sources. ${ }^{59} \mathrm{He}$ acknowledged Zaidān's

55 J. Zaidān, Fatāt Ghassān, Beirut: Manshūrat Maktabat al-Hayāh, n. d., part I, p. 75; see Riḍā's review of it, al-Manār, vol. 6/10, pp. 392-398.

${ }_{56}$ Zaidan, ibid, passim, pp. $32-36$ \& p. 72.

57 Al-Manār, vol. 7/13 (1 Rajab 1322/11 September 1904), pp. 514-518.

${ }^{58}$ J. Zaidān, Tārìkh al-Tamaddun al-'Islāmī, 5 vols., Cairo, 1901-1906.

59 Al-Manār, vol. 8/13 (Rajab 1323/August 1905), pp. 511-512. 
initiatives as unprecedented in furnishing the history of Islam, and saw this specific work as 'a useful example for Arab readers. ${ }^{60} \mathrm{He}$ moreover urged other Arab historians to follow his steps. ${ }^{61}$ He again disapproved of Muslim attacks on the book as 'unfair to recompense those who make efforts to serve [Muslims] by constantly stressing their lapses before giving mention to the benefits of their works.' 62 Rị̣ā continued to give his positive assessment for Zaidān's works in the following years, while he persistently kept requesting other authors to critically review the author's historical data. ${ }^{63}$

However, by 1908 al-Manār turned to sketch its first detailed criticism of Zaidān's work on pre-Islamic history by publishing two articles by Aḥmad 'Umar al-'Iskandarī (1875-1938), a teacher of Arabic Literature, in which he berated Zaidān's work. In his articles, al-Iskandarī criticised Zaidān's ability to write on Islamic history. Although his effort deserved appreciation as a historical piece of work, it should have been written in a more accurate way. ${ }^{64}$ In January 1912 al-Manār published a sharper criticism launched by the Indian scholar Shiblī al-Nu'mānī (1869-1914), ${ }^{65}$ who accused Zaidān of attempting to belittle the Arabs and to abuse them. Like Riḍā, Nu'mānī had been earlier on good terms with Zaidān. At the beginning of their relation, Nu'mānī did not believe any accusation against Zaidān of blatantly misrepresenting Arab history. ${ }^{66}$ At a certain point, however, Nu'mānī shifted his attack to the personal integrity of Zaidān by demonstrating that his sole attempt was to deliberately falsify and

\footnotetext{
${ }^{60}$ Al-Manār, vol. 5/14, p. 552.

${ }^{61}$ Al-Manār, vol. 7/4 (Șafar 1322/May 1904), p. 149.

${ }^{62}$ Al-Manār, vol. 7/13, p. 518.

${ }^{63}$ See, al-Manār, vol. 8/16 (Sha'bān 1323/October 1905), p. 638; vol. 9/11 (Dhū al-Qida 1324/December 1906), pp. 873-875; $10 / 7$ (Rajab 1325/September 1907), p. 553, 11/8 (Sha'bān 1326/25 September 1908), pp. 619-620.

${ }^{64}$ J. Zaidān, al-'Arab Qabl al-Islām, Cairo, 1907. See, A. al-'Iskandarī's critique, 'Ilmāmah bī Kitāb Tārīkh al-'Arab Qabl al-'Islām,' al-Manār, vol. 11/9 (Ramaḍān 1326/October 1907), two articles, pp. 681-750 \& vol. 11/10 (Shawwāl 1326/23 November 1908), pp. 780-787. Cf., al-Iskanadrī's contributions to the Arabic language, al-Manār, vol. 10/12 (Dhū al-Hijja 1325/February 1908), pp. 887-915.

${ }^{65} \mathrm{He}$ was a member of the Salafiyyā movement in India. He is the founder of Nadwat al-'Ulamā in Lucknow. He wrote many works on the history of Islam. More about his intellectual life, see for example, Ahmad Anis, 'Two Approaches to Islamic History: A critique of Shiblī Nu'manī's and Syed Ameer Alī's interpretations of history,' unpublished PhD dissertation, Temple University, 1980; Mehr Afroz Murad, Intellectual Modernism of Shiblī Nu'mānì: An exposition of religious and political ideas, New Delhi, 1996.

${ }_{66}^{6}$ Various letters, quoted in Ware, op. cit., p. 199.
} 
change the truth about Islamic history. The motive for Nu'mānī's response was that Zaidān had engaged in circulating 'intrigues' through the publication of such works, while nobody took the initiative to oppose him. ${ }^{67}$ Zaidān, on the other hand, habitually eulogised Nu'mānī's work and paid tribute to his scholarly prestige among Indian scholars. But this was no justification for Nu'mānī to quit his religious 'zealousness' by giving concessions in matters of religious beliefs. He also made it clear that he was not ready to 'accept his [Zaidān] praise in return for allowing him to attack the Arabs. ${ }^{368}$

In October of the same year, two other articles by al-'Iskandari appeared in Rị̣ā's journal in which he again sharply criticised Zaidān's work on the history of Arabic literature.$^{69}$ Some of Zaidān's shortcomings, according to al-'Iskandarī, were his many mistakes in giving references and documentation for his data, his incorrect conclusions, contradicting information, his imitation of orientalists-who sometimes formulate their views without any verification, and his literal application of the theory of evolution in all aspects. ${ }^{70}$

Riḍa gave the views of both al-'Iskandari and al-Nu'mānì more credibility by reprinting their criticisms in a separate treatise together with another article by the Jesuit Louis Cheikho, the editor of alMachreq. ${ }^{71}$ In his preface to the treatise, Riḍa also withdrew his support by saying that Zaidān, as a non-Muslim, wrote his history without any proper qualification in Islamic knowledge from real authoritative scholars. Zaidān, Riḍā contended, relied on the works of Western orientalists in his approach of collecting his historical data rather than making an effort to directly rely on Islamic sources. For this reason, his works came out with the gravest of errors. However, Riḍa denied that he had anything to do personally with these criticisms

${ }^{67}$ Al-Manār, vol. 15/1 (Muharram 1330/January 1912), p. 59.

${ }^{68}$ Ibid., p. 60.

${ }^{69}$ J. Zaidān, Tārīkh 'Adāb al-Lugha al-'Arabiyyā, 4 vols, Cairo, 1911-1914.

${ }^{70}$ Al-Manār, vol. 15/10 (Shawwāl 1330/October 1912), pp. 743-744.

${ }^{71}$ Kitāb 'Intīqād Kitāb Tārīkh al-Tamaddun al-'Islāmī, Cairo: Mațba at al-Manār, 1330/1912; cf. Philip, Gurgi, pp. 64-65. It is interesting to know that in his early review of this book in 1904, Rị̣a insisted that Zaidān never intended to be dishonest in dealing with Islamic sources, unlike the Jesuits whom Riḍa considered to intentionally falsify such sources in their attack on Islam, al-Manār, vol. 7/13, p. 518. Louis Cheikho was, for instance, one of his main antagonists. Cheikho considered Protestants and members of the Syrian Protestant College as a natural object of wrath, Philip, Gurgi, p. 60. 
and that al-Nu'mānī (and other authors) must take the responsibility. ${ }^{72}$

On his part, Zaidān was frustrated by this unexpected Manārist campaign against his works. A few months after the appearance of these articles in al-Manār, he complained to his son Emile that the views of al-Iskandarī and al-Nu mānī showed some aspects of religious hatred and fanaticism that he had had to contend with occasionally during his career. They were therefore not worthy of any answer. ${ }^{73}$ Riḍa and al-Nu ${ }^{4}$ ānī, whom he had considered as good friends, had now turned out to be his adversaries. When al-Nu'mānī was still extensively involved in writing against Zaidān's work in al-Manār and elsewhere, one of al-Hiläl's Muslim readers in Egypt tried to console the latter for al-Nu'mānī's harsh attack on his integrity. In his reply to this reader, Zaidann maintained that he was perplexed by reading these attacks, and had no clear answer why Riḍa and al-Nu'mānī had turned against him in such a way. ${ }^{74}$ However, he had explicitly mentioned the direct reason behind their campaign in an earlier letter to his son Emile:

I read al-Manār and saw, what you saw too. Grief prevailed over all other feelings in me. Not because this foolish criticism had any influence upon me. Indeed, the station of al-Hilāl is too lofty as to be hit by any tasteless slander. But I was grieved by the deterioration of the character of our writers to such a level, that even from al-Nu'mānī, the greatest scholar of India, emanated phrases that even the rabble would be ashamed to use. With all this we were friends for twenty years and our relations were amicable. When I read his criticism I wrote him a letter, reproaching him in very strong terms. A copy of it you will find enclosed [...] As for the owner of al-Manār he is excused by his exasperation with al-Hilall, the success of our books, our fame. ${ }^{75}$

In June 1910, Zaidān was invited to teach a course in Islamic history at the recently founded Egyptian University, but a few months later he was to learn that the University withdrew his appointment. ${ }^{76} \mathrm{He}$

72 Ware, op. cit., pp. 198-199.

73 Letter to Emile, 14 November 1908, as quoted in Ware, ibid., p. 198.

74 A question from a certain Muhammad Mușțafā from Alexandria, see, 'Bāb al-Su'āl wā al-Iqtirāh,' al-Hilāl, vol 20/9 (June 1912), pp. 562-563.

75 Letter to Emile, Cairo, March 28, 1912; as translated and cited in Philip, Gurgi, pp. 216-219.

76 Ibid., pp. 66-67; more about the affair, see, Donald Malcolm Reid, 'Cairo University and the Orientalists,' International Journal of Middle East Studies 19/1, 1987, pp. 62-64 (Quoted below, 'Cairo'). 
suspected that Ridā had a hand in opposing his post at the university. He was convinced that the founder of al-Manār was angered by the appraisal letter of Prince Muhammad 'Alī (b. 1872) in which he maintained that before the appearance of al-Hilal nobody mentioned the history of Islam. Another factor for irritation was, according to Zaidān, Rị̣ā's failure to imitate him in writing historical novels about Islam. In 1905, Rịā had approached his Syrian friend Sheikh 'Abd al-Hamīd al-Zahrāwī (1871-1916) to help him to compose a series of historical novels about Islam because nobody had written about this subject in Arabic earlier. ${ }^{77}$ Referring to this imitation, Zaidān ended his letter to his son: 'regardless of the fact that my novels fill his library and he has read all of them. If this did not change his irritation, how can we blame him that his vexation increased when he started with his project and did not even finish the first novel. ${ }^{78}$

In truth, Rị̂ā never openly accused Zaidān of any evil intention to misrepresent the history of Arabs and Islam. He explained his own reasons for publishing this collection of criticisms. Besides his incapability of writing on Islamic history, Riḍa made it clear that he was highly concerned that the Turkish translation of Zaidān's works might add fuel to the fire of Young Turk chauvinism. ${ }^{79}$ The Turkish translation of his work was done by the Christian Zakī Maghāmiz of Aleppo, who was known for his anti-Arab sentiments. In one of his letters, Maghāmiz complained to Zaidān that the illustrations in his book showed Arab civilisation to be too superior. Maghāmiz also took part in the Turkish project of translating the Qur'ān. At another occasion, Rị̣a suspected Maghāmiz of intentionally misrepresenting the Qur'àn through his assistance in the translation. ${ }^{80}$ Zaidān later became a sympathiser of the Young Turks Revolution and strongly opposed any Arab attempt to form independent organisations, such as the Decentralisation Party of Riḍa and his group. Riḍa was very disappointed in Zaidān's stance towards the Turks against the Arabs. ${ }^{81}$

77 Philip, Gurgi, p. 219.

78 Ibid.

79 The last volume of the Arabic edition of Zaidān's work appeared in 1906. When it had been translated into Turkish six years later, Riḍa made his major effort to criticise it. Ibid, p. 65.

${ }^{80}$ Al-Manār, vol. 25/10 (Sha'bān 1343/March 1925), p. 794.

81 Ibid., pp. 107-109. 
This attitude became clearer especially after Zaidān's death. Not long after his death, Rị̣ā (who was also present at his commemoration ceremony) wrote a biography in which he discussed in detail the late Zaidān's sympathy to the ideas of Ottomanism. For Riḍā, Zaidān was one of the pillars ( $r u k n$ ) of the modern Arab renaissance (nahda). However, after his trip to Istanbul (1908) Zaidān tried to revive the $s^{\prime} u^{\prime} \bar{u} b \bar{\imath}$ (anti-Arab sentiments) beliefs among the Christian intelligentsia, and became convinced of the validity of absorbing the Arab provinces back into the Empire. He considered Zaidān's tendency as an attempt to champion the Turkish culture over the Arabs. Riḍā, who previously praised his works on Arab civilisation, now viewed them as an attack on the Arab identity. For this reason, he allowed Nu'mānī's criticism to be published in his journal in order to prevent the Turks from using Zaidān's works as a source of criticism against the Arabs. ${ }^{82}$

\subsubsection{Ya'qūb Șarrūf and Fāris Nimr (al-Muqtațaf)}

As has been mentioned above, al-Muqtataf was one of the Arabic periodicals that brought Ridā into contact with the Western world during his Syrian years. It was founded by the Syrian Christians Ya'qūb Șarrūf (1852-1927) and Fāris Nimr (1856-1951) after their arrival in Egypt in 1876. The great contribution of this journal was the revival of the Arabic language by introducing science and technology to an initially narrow, but ever-increasing Arabic reading public in a simple and sound language. ${ }^{83}$

Al-Muqtataf met with strong opposition from entrenched traditionalist circles in the Muslim world. When its first issues arrived in Baghdad, for instance, conservatives in all communities, Sunnì and Shî̀ $\mathbf{1}$, Christian and Jewish resisted it because it preached new and 'dangerous' doctrines. Only some of the younger generation welcomed it. ${ }^{84}$ But its appeal to the awakening needs of the Arabic-

\footnotetext{
${ }^{82}$ Al-Manār, vol. 17/8 (Sha'bān 1332/24 July 1914), pp. 638-640; Ware, op. cit., pp. 199-200.

${ }_{83}$ L.M. Kenny, 'East versus West in al-Muqtațaf 1875-1900,' in D. Little, ed., Essays on Islamic Civilization presented to Niyazi Berkes, Leiden, 1976, p. 145; More about its linguistic contributions, see, Adrian Gully, 'Arabic Linguistic Issues and Controversies of the Late Nineteenth Centuries,' Journal of Semitic Studies 42/1, 1997, pp. $75-120$.

${ }^{84}$ Hourani, Arabic Thought, p. 247.
} 
speaking East was broad enough to quickly win the support of Muslim intellectual leaders. ${ }^{85}$

Riḍa had friendly relations with the editors of the journal, and never had any confrontations with them. He always paid tribute to the skills of the editors and the quality of their journal. His attitude should be explained against the background of al-Muqtataf s position towards religion in general, and Islam in particular. The journal in many places stressed that there was no conflict between science and religion, and that the revealed Scriptures were not to be read as scientific textbooks. ${ }^{86}$

It was Jurjī Zaidān who recommended Riḍā to the founder of al-Muqtațaf. He also informed Șarrūf about Rị̣ā's coming to Egypt. In their earliest meeting, Riḍa discussed with him various subjects, including his main goal of establishing a journal in which he intended to propagate religious reform and the reconciliation between Islam and Christianity. In their discussion, Șarrūf explained to Riḍa the difference between Syria and Egypt by attributing the spread of knowledge and reform in the Syrian territory to the consciousness of its people. But in Egypt its spread was due only to the efforts made by its government to establish freedom. As Șarrūf was greatly interested in philosophy, Riḍa made it clear that his intended journal was also an attempt to remove the idea in the minds of the majority of Muslims that philosophy contradicts religion. ${ }^{87}$

In his speech during the tenth anniversary of al-Manār, Șarrūf expressed his admiration for Rị̂ā's journal and its role in 'serving religious freedom and fighting innovations and superstitions.' He told the audience about his primary impression of Riḍa when he read the early issues of his journal. He became convinced at that moment that Muslims would one day esteem the reforms of Riḍa and his teacher 'Abduh in Islam just as Calvin and Luther were highly regarded as reformers of Christianity. Muslims, Șarrūf went on, were in dire need of that kind of reformation, which was strongly endorsed in Riḍa's journal by combining religion and civilisation. He also stressed that Riḍā's work should please Christians as well as other minority groups

\footnotetext{
${ }^{85}$ Kenny, op. cit., p. 153.

86 Ibid., p. 142.

87 Riḍā's diary, 1897-1898.
} 
in the East, as 'the Near Orient would never advance without the progress of Muslims. ${ }^{\text {' } 8}$

Ridā's initial impression of the editors of al-Muqtataf was that they tended to be 'atheists' or 'antagonists' in faith. ${ }^{89}$ Their later discussions on the divine and other religious issues revealed to him that they (especially Șarrūf) were not total disbelievers in the existence of God and His might over the world. He enthusiastically quoted the response of al-Muqtațaf to a letter by the Coptic writer Salāma Mūsā (more about him below) in which he declared his pride in becoming an agnostic and gave his full sympathy to socialism versus any faith in God. Sarrūf argued that 'the rejection of God is the road towards the

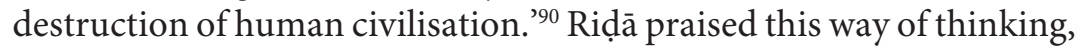
which to a certain degree resembles the Qur'ānic manner of proving the existence of God. ${ }^{91}$

Riḍā's admiration of al-Muqtațaf and its founders made him propose an event to celebrate the golden jubilee of the journal. ${ }^{92}$ In his speech during that event (30 April, 1926), Riḍa admitted the scientific contributions of the founders of al-Muqtataf to the revival of the Arabic language and its serving the whole umma. However, he was certain that due to the stagnation of scientific and literal movements in the Arab world al-Muqtataf did not receive the recognition or the circulation it deserved in its time. Riḍa expressed his strong belief that 'the divine destiny was the moving factor in choosing the founders of al-Muqtataf to be one of the corners of the Arabic scientific renaissance. ${ }^{93}$ He maintained that it was predestined by the divine providence that the Americans would come to the East to establish their missionary college in Beirut. In that institution the founders of al-Muqtataf had the chance to become very qualified in their native language and skilled in other languages. The divine providence, Riḍā went on, was also behind their departure with their journal to Egypt

${ }^{88}$ Al-Manār, vol 10/9 (Ramaḍān 1325/November 1907), pp. 717-718, cf. 'Al-Iḥtifāl bi-al-Manār,' al-Muqtațaf, vol 33/1 (January 1908).

${ }^{89}$ Al-Manār, 'Al-Dīn wā al-'Ilhāe wā al-'Ishtirākiyya: Naṣr al-Muqtațaf al-'Imān 'alā al-Ta ț̣il,' vol. 13/12, pp. 912-921.

90 Ibid., p. 915.

91 Ibid.

92 Al-Manār, 'Athar al-Muqtațaf fī Nahḍat al-Lughah al-'Arabiyya,' vol. 27/10 (Jumādā al-'Ākhira 1345/January 1927) pp. 786-791.

93 Ibid., p. 789. 
in order that they could enrich the Arabic language with their vast knowledge of science and foreign languages. ${ }^{94}$

\subsubsection{Shibli Shumayyil: A Fervent Darwinist}

Shiblī Shumayyil (1860-1917), of Syrian Greek Catholic origin, was a graduate of the medical school of the Syrian Protestant College. He also studied medicine in Paris before he settled in Egypt, where he practised his profession as a physician and took part in the public and intellectual life of the country. As a young man he clashed with the staff of the College over the theories of Darwin on the evolution. He was a sharp proponent of scientism, and stood out as the foremost populariser of Darwinism. The Arab world became acquainted with the theory of evolution through Shumayyil's translation of Darwin's works into Arabic. ${ }^{95}$

Like Riḍa, Shumayyil escaped the Hamidian tyranny, and sought liberty in Egypt. Despite his agnostic and secularist line of thought, Shumayyil's general views of politics, religion and sympathy towards Islam must have been the greatest motive for Riḍa to strengthen their relationship. In Shumayyil's view, religion was a factor of division: not religion itself, but the religious leaders, who sowed discord between men; and this kept society weak. He further extended his view to postulate that all types of extreme solidarity taking the shape of national fanaticism had the same danger as religion, because they lead to the division of society. For him, Christianity sprang from egoism: from the love of domination on the part of religious leaders, and the ordinary man's desire for individual survival. When Lord Cromer criticised Islam in his Modern Egypt as 'a social system [that] has been a complete failure, ${ }^{96}$ it was the Christian Shumayyil who rushed to the defence of Islam by stating that it was not Islam, nor the Qur'ān; but the power of the Sheikhs which kept the umma weak. ${ }^{\prime 97}$

${ }^{94}$ Ibid., pp. 790-791.

${ }_{95}$ More about him, see, S. Shumayyil, Majmū'at al-Duktūr Shiblī Shumayyil, 2 volumes, Cairo: Mațba'at Al-Ma'ārif, n.d.; Jean Lecerf, 'Shibli Shumayyil, métaphysicien et moraliste contemporain,' Bulletin d'études Orientales 1, 1931, pp. 153-86; Donald M. Reid, 'The Syrian Christians and early Socialism in the Arab World,' International Journal of Middle Eastern Studies 5, 1974, pp. 177-193; Hourani, Arabic Thought, pp. 248-253.

96 Lord Cromer, Modern Egypt, New York: The Macmillan Company, 1908.

97 See his article, 'Al-Qur'ān wā al-'Umrān,' firstly published in al-Mu'ayyad (1908), reprinted in his Majmü'at, vol. 2, pp. 57-63; cf. Hourani, Arabic Thought, pp. 250-253. 
In his eyes, there was no difference between Christianity and Islam (though he favoured Islam in other occasions) with regard to their inclination to achieve social equality among people, ${ }^{98}$ but his method of comparison between Islam and Christianity was sometimes seen by Christians as an attack on Christianity. ${ }^{99}$

Shumayyil's favourable impression of Riḍā was reflected in his regular praise for him and his journal. For him, Riḍā was a typical Muslim reformer who was 'keen in his Manār on unshackling [...] Islam from all fetters imposed by [conservative] scholars as an attempt to liberate religion from any blemish, and to make it attain its ultimate goal through al-'Amr bi al-Ma'rūf wā al-Nahy 'an al-Munkar (to enjoin what is good and forbid what is wrong).' 100

Riḍā considered Shumayyil's positive views of Islam as a kind of recognition by non-Muslims regarding the authenticity of its divine message. ${ }^{101}$ Shumayyil once wrote to him (see, appendix V): 'You look at Muhammad as a prophet and make him great, while I look at him and make him greater. Although we are in contrast with each other, what we have in common are broad-mindedness and sincerity [...]and that makes our bond of friendship stronger.' ${ }^{102}$ Despite the fact that Riḍa was appreciative of Shumayyil's high esteem of the Prophet of Islam, he did not accept his statement that the Prophet's political career had been stronger than his prophecy. ${ }^{103}$

\footnotetext{
${ }_{98}$ Majmü'at, vol. 2, p. 58.

${ }^{99}$ Ibid., pp. 72-73.

100 The article was firstly published in the Egyptian daily al-Akhbār, 1907. It has been reprinted in Majmü 'at, pp. 243-244.

${ }_{101}$ Al-Manār, vol. 11/1, pp. 10-11

${ }^{102}$ Letter from Shumayyil to Riḍā, n.d., the letter contained a poem by Shumayyil
} on the Prophet. It was also published in al-Manār, vol. 11/1, p. 11.
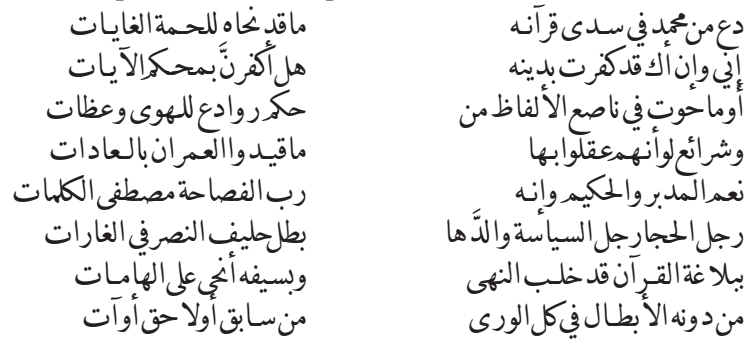

103 Ibid., p. 11 
In a letter to Riḍā, 'Abd al-Qādir al-Qabbānī (1848-1935), ${ }^{104}$ a Syrian journalist, disapproved of Shumayyil's propagation of Darwinism as a sign of total rejection of religion. ${ }^{105}$ Riḍa an was not alarmed by Qabbānī's accusations, and saw them as little more than exaggeration, since the theories of Darwin were not 'evil' and did not in principle conflict with Islamic fundamental doctrines. Darwinism was merely a scientific school and should not be studied within the context of religious thought. Despite Shumayyil's agnosticism, Riḍa defended him as somebody who never intended exclusively to disprove religions. For him, Shumayyil was one of the most erudite and independent people in his thinking. Just as with many educated Christians, the reason behind his scepticism was his training in the exact sciences according to the European traditions without having any parallel religious education that would convince him of the agreement between science and religion. He reminded his questioner that Shumayyil, on several occasions, had admitted that 'there is no socialist religion, except the religion of the Qur'ann. ${ }^{106}$ Instead of accusing the Christian Shumayyil of unbelief, Rị̣ā requested Qabbānī and other Muslim writers to sustain him in his struggle against superstitions prevailing among Muslims. They should rather spare their efforts to fight those 'ignorant scholars' of Islam, whose ideas were, in his view, more dangerous to their religion than such theories as Darwinism. ${ }^{107}$ If his mission succeeded, Riḍa dared to guarantee that the educated class of non-Muslims (physicians, chemists, astronomists, socialists, lawyers and politicians) would one day convert to Islam!

As far as Shumayyil was concerned, Rị̣a had a strong wish that he would once adopt Islam. He was also convinced that if he just had had the chance to study Islam in the way he had studied Darwinism, he would have become a Muslim. Rị̣ā once asked Shumayyil: 'due to your respect of the Qur'ān and the Prophet you are symbolically

104 The founder of the journal Thamarāt al-Funūn (Fruits of the Arts, founded in 1876). For more about the journal's history, see Donald Ciota, 'Thamarat al-Funun: Syria’s First Islamic Newspaper, 1875-1908,' PhD Dissertation, University of Chicago, 1979.

105 The letter was sent to Riḍā as a result of Qabbānī's reading of one of Shumayyil's articles in al-Hilāl, (June 1909); 'al-Duktūr Shiblī Effendi Shumayyil,' al-Manār, vol. 12/8 (Sha'bān 1327/September 1909), pp. 632-637.

106 Ibid.

107 Ibid. 
a Muslim!' In his answer, Shumayyil answered: 'No, I am a Mohammedan!'108

When the Iraqi-Kurdi poet Jamīl Șidqī al-Zahāwī (1863-1936) published his article on women's rights in Islam in the Egyptian daily al-Mu'ayyad (August 1910), he was dismissed from his job as a teacher of Sharī a at the College of Law in Baghdad. Many Muslim writers in Iraq, Egypt, Syria and elsewhere accused him of 'infidelity' and 'atheism.' ${ }^{109}$ In that article, Zahāwī criticised the position of women in Islam, the veil, the system of inheritance and Islamic regulations of divorce as unjust. In his writings, Zahāwī in general denied the existence of God as the Maker of the world, defied the authority of the Qur'ān and was annoyed with the daily prayers and Ramadan. ${ }^{110}$

Zahāwī was influenced by Shumayyil's Arabic translation of Darwin's works. ${ }^{111}$ As a result of the anti-Zahāwī campaign, Shumayyil requested Riḍā to write his views as a Muslim scholar on the ideas of the Iraqi poet. In December 1910, Rị̣ā responded to Shumayyil's request. He was very cautious not to label Zahāwī as an infidel, although he could be seen as an 'apostate' on the basis of his antiIslamic statements. Riḍa, on the other hand, was more inclined to remind those who supported Zahāwī (such as Shumayyil) that his expression of such views was 'scorn' and 'ridicule' of Islam as the official religion of the Supreme Porte. His words should not be defended under the rights of freedom of expression. ${ }^{112}$ Putting in mind that he was reacting at Shumayyil's request (whom he earlier

108 See Riḍā's review of Shumayyil's Arabic translation of the theories of Darwin, al-Manār, vol. 13/5 (Jumādā al-'Ūlā 1328/June 1910), pp. 374-376.

109 The article was entitled: 'al-Mar'ah wā al-Difā' ' anhā-Ṣawt Islāhī min al-'Irāq.' See the text of the article in 'Abd al-Rāziq al-Hilālī, al-Zahàwī: al-Shā'ir al-Faylasūf wā al-Kätib al-Mufakkir, Cairo, 1976, pp. 190-189. A certain Muhammad Sa īd al-Naqshabandī wrote his al-Sayf al-Bāriq fì 'Unuq al-Māriq against Zahāwī's views on women's rights. Later Riḍa published a treatise by the Najdī Muslim scholar Sulaymān b. Saḍmān al-Najdī (d. 1930) in Maṭba'at al-Manār in which he attacked Zahāwī: al-Dìà̄ al-Shāriq fī Radd Shubuhāt al-Māziq al-Māriq, Mațba at al-Manār: Cairo, 1925. Cf. Sadok Masliyah, 'Zahawi: A Muslim Pioneer of Women's Liberation,' Middle Eastern Studies 32/3, 1996, pp. 161-171. For more about him, see, G. Widmer \& G. Kampffmeyer, 'Ubertragungen aus der neuarabischen Literatur. II Der iraqische Dichter Gamil Sidqi az-Zahawi aus Baghdad,' Die Welt des Islams 17/1-2, 1935, pp. 1-79; Wiebke Walther, 'Camil Sidqi az-Zahawi: Ein irakischer Zindiq im ersten Drittel dieses Jahrhunderts,' Oriens 34, 1994, pp. 430-450.

110 Sadok Masliyah, 'Zahawi's Philosophy and His Views on Islam,' Middle Eastern Studies 12/2, 1976, pp. 180-183.

111 Ibid., p. 180.

112 Al-Manār, vol. 13/11 (Dhū al-Qi'da 1328/Decmebr 1910), pp. 841-846. 
had praised for his independence of thought), Riḍa argued that Zahāwī should have pursued his mission of reforming the situation of Muslims in another way: by addressing those superstitions widely spread among Muslims, instead of attacking the religious fundamentals of Islam. Zahāwī was found by Riḍa as to have ridiculed the Islamic Law; and therefore was not entitled to teach it to Muslim students. In order to avoid chaos in society, he strictly forbade Muslim individuals to physically attack him, nor to raid on his property; but they were allowed to manifest their objections in all peaceful means. ${ }^{113}$

Forty days after Shumayyil's death (January 1, 1917), a memorial ceremony was held at the Syrian Club in Cairo. In an article in his journal, Riḍa eulogised the late Shumayyil as one of the 'unique and sincere seekers of civil and social reform. ${ }^{114}$ Shumayyil's influence, according to him, was extended to his genuine efforts for the socialist cause besides his profession as a physician. In his comment on Shumayyil's affinity with Darwinism, Riḍa was astonished that the Catholics (especially the Jesuits) did not publicly attempt to criticise Shumayyil and his adherence to such theories. According to him, some priests were said to resist Shumayyil's 'infidelity' and propagation of Darwinism by discouraging Christian patients to visit his clinic for treatment. But the majority of Christians acknowledged his social reform despite his atheism. In Riḍā's understanding, Muslims did not see his manifestation of unbelief as a reason for ignoring him. They treated him, however, as a non-Muslim physician and sociologist. ${ }^{115}$ Shumayyil's appreciation of the Prophet's personality and his social role in Arabia enabled Riḍa to consider his adherence to atheism as less destructive. He believed that the only reason he did not embrace Islam was that he studied Islam while being an agnostic, who did not believe in the existence of God. For Riḍa, Shumayyil's attribution of the Prophet's success only to his human traits had prohibited him from studying his achievements as a Prophet dispatched by God to humanity. But in spite of Sumayyil's materialism, Riḍa praised him for his 'compassion, generosity, sincerity, bravery and sense of honour.'116

${ }^{113}$ Ibid., pp. 844-845.

114 Al-Manār, vol. 19/10 (Jumādā Al-'Ākhira 1335/April 1917), p. 625.

${ }_{115}$ Ibid., pp. 625-626.

116 Ibid., p. 629; after his eulogy of Shumayyil in al-Manār an anonymous graduate of Al-Azhar launched a campaign against Rị̣ā accusing him of infidelity for his 


\subsection{5. 'Ibrāhìm al-Yāzijī}

Sheikh 'Ibrāhīm al-Yāzijī (1847-1906) was one of the most well-known Christian Arab literary figures in the late nineteenth century. His father Nașîf al-Yāzijī was also a man of letters and a great Arab philologist. Sheikh Ibrāhīm had contributed to the Jesuit Arabic translation of the Bible. Before that, he had embarked upon learning Hebrew and Syriac. By 1889, he became a freemason in Syria, and migrated to Egypt in 1897 with other Syrian publicists, where he established or contributed to many Arab magazines. ${ }^{117}$ He belonged to the group of Christian intellectuals who participated immensely in the revival of the Arabic language in modern times, and was one of the earliest proponents of Arab nationalism as well. For him, the Arabs were 'the most remarkable people among all nations.' ${ }^{118}$

During his early years in Syria, Riḍā had no personal contact with al-Yàzijī, but he formed an unfavourable judgement of him on the basis of stories attributed to him that he had attacked the Qur'ān and its language. At that time, Riḍā made no effort to get acquainted with him. Later in Egypt his image temporarily changed when he met with al-Yāzijī at the Egyptian Book Association. According to al-Manār, al-Yāzijī showed Rị̣ā 'friendliness, gentleness and good manners.' After that meeting, Riḍa started to praise him regularly as one of the most knowledgeable Syrian Christian literary figures. What attracted Riḍā to al-Yāzijī besides his earnest contributions to the revival the Arabic literary was his enthusiasm in opposing the archaic and foreign elements in the Arabic journals of his time. ${ }^{119}$

In a personal article written two years later entitled: 'We and al-Yāzijī', Riḍā, however, noted that many Syrian Christians were disappointed with al-Yāzijī's pride and arrogance; and that his feeling of superiority had prevented him from sharing his knowledge with

acceptance of Darwinism and having put Shumayyil above the Rightly-guided Caliphs. See, al-Manār, vol. 20/1 (Shawwāl 1335/July 1917), p. 6.

${ }_{117}$ He established with other people newspapers and magazines before his migration to Egypt, such as al-Najāh (1872), and al-Tabīb (co-editors Khalīl Sa ādeh and Bishārah Zalzal, 1884-1885). In Egypt he established two: al-Bayān (1897-1989), and al-Diyā' (1898). For more about his life and works, see, 'Isā Mikhā'īl Sabā, al-Sheikh 'Ibrāhìm al-Yāzijī (1847-1906), Cairo: Dār al-Ma'ārif, 1955.

118 Dawisha, op. cit., pp. 25-26.

119 Al-Manār, vol. 4/15 (Rajab 1319/October 1901), pp. 590-591. 
others. ${ }^{120}$ Riḍa pointed here to Yāzijī’s criticism of Ya qūb Șarrūf, the founder of al-Muqtataf, for his use of colloquial or foreign words, and for occasional slight grammatical mistakes in his writings. Riḍā's view of al-Yàzijī was that he himself often made mistakes in his writings. ${ }^{121}$

In 1903, one of the missionary magazines attacked the Qur'ān on the basis of one piece of work attributed to al-Yāzijī in which he was said to assault the Qur'ānic language. ${ }^{122}$ In his comment on Riḍa's stance, al-Yāzijī blamed al-Manār for causing 'chaos' and 'disturbance of thoughts' among the public by stirring up such accusations with no verification. ${ }^{123}$ On the other hand, Ridā accused him of arrogance, stating that if he had been really innocent, he should have taken the effort to clear his name by at least writing a letter to the editorial of al-Manār. Riḍa repeated that al-Yāzijī hardly had any sincere friends whether in Syria or in Egypt. He also concluded that al-Manār's critical response to him should not be seen as an attack on al-Yàzijī's person, but against the background of its general stance against missionary writings. There was thus in his view no contradiction in his eagerness to establish concord and friendship with fair Christians. ${ }^{124}$ Al-Yāzijī died three years later, and al-Manār was silent in giving any further responses to him during these years.

\subsubsection{Khalīl Sa'ädeh}

Very little is mentioned in al-Manār about Riḍa's relation with the Syrian Orthodox Khalil Sa ādeh (1857-1934), whose significance actually lay in their co-operation in editing the Arabic translation of the controversial Gospel of Barnabas (see chapter 5). In view of the importance of the Gospel, it might be useful to discuss their relation in the light of some biographical information about Sa ādeh in order to place him in the intellectual and political setting of our discussion.

Sa'ādeh was known as a 'politically engaged man of letters.' He was born in Shuwayr, Mount Lebanon, and studied medicine at the Syrian Protestant College. In 1882 he was chosen as the spokesman of the

120 'Naḥnu wā al-Yāzijī', al-Manār, vol. 6/8 (Rabī' al-Thānī, 1321/July 1903), p. 318.
${ }^{121}$ Ibid., p. 319.
122 Ibid.
123 Ibid.
124 Ibid. 
student movement at the College. After his graduation in 1883 he became a staff member of the editorial board of the short-lived scientific and medical review al-Tabīb in Beirut (mentioned above). In the following years, he worked as a medical advisor for the Ottoman government in Palestine. In 1901 he left Syria for Egypt, where he eventually stayed till 1913. Like many of his Syrian fellows, he became involved in journalism, and wrote articles for al-Ahräm. He also became a correspondent of English papers, such as The Times and The Standard. ${ }^{125}$ This period of his life witnessed an intense intellectual productivity and political involvement. He was able to read in French, Spanish, Portuguese, and Latin. Besides his work as a journalist, Sa ādeh gained special qualifying skills in English and was able to write literary works in that language. He in fact wrote two novels: The Syrian Prince (London, 1893) and Cesar and Cleopatra (London, 1895). He compiled also an Arabic-English Lexicon during his stay in Cairo in 1911. ${ }^{126}$

Later he moved to Argentina, where he lived during World War I, until 1919. In 1919, he accepted an invitation from the Syrian community of Sao Paolo and moved to Brazil. There he founded the newspaper al-Jarìda, which developed into a cultural magazine and subsequently changed its name to al-Majalla. From 1930 until his death in 1934 he was the editor of the prestigious literary magazine al-Rābița. During this period in South America, he did not write any direct contributions to Riḍā's journal. But from the Diaspora he had been sharing with him the struggle for the complete independence of Greater Syria. He also founded the Syrian League and the National Democratic Party to support the Syrian quest for complete independence. ${ }^{127}$

${ }^{125}$ C. Schumann, 'Nationalism, Diaspora and 'civilisational mission': the case of Syrian nationalism in Latin America between World War I and World War II,' Nations and Nationalism 10, 2004, pp. 599-618. More about him, see, Ali Hamie, 'Khalil Saadeh: L'homme en l'œuvre: 1857-1934,' unpublished PhD dissertation, Sorbonne, 1986 (Quoted below, 'L'homme'). Thanks to Dr. Hamie for sending me a copy of the thesis. It has been recently translated into Arabic, id. al-'Alläma al-Duktūr Khalīl Sa'ādeh, sīratuh wā A'māluh, Beirut: al-Furāt lī al-Nashr wā al-Tawzì', 2007 (Quoted below, al-'Allāma). My gratitude is due to my colleague Abdullāh Șofān of the American University in Beirut for sending me a copy of the book from Beirut.

${ }^{126}$ See the speech delivered by his granddaughter Sofia Sa'àdeh during the event of his honor held by the branch of the Society of Feminist Development in his village Shuwayr in 2002, p. 3; available at http://www.shweir.com/ain_el_assis.htm, accessed, 20 November 2006.

${ }^{127}$ Schumann, op. cit., p. 606. 
Sa ādeh regarded journalism as the measure for the advancement of nations, and the mirror of their morals and cultural refinement. ${ }^{128}$ According to Schumann, Sa âdeh believed that the state of journalism was tied to the state of the nation itself. The nation would decline if the press declined and stagnated. If the nation woke up and joined the 'other living nations,' it would be most visible in the awakening of its press. Sa'ādeh wrote: '[Today] the hidden forces of the nation become evident in the advanced press. Its working spirits as well as its thinking brains become apparent, and its splendid literature emerges. There is no advanced press, however, unless it is based on excellence, unless its motto is knowledge and unless its strength is respect for the individual. Its content is nourishment for the brain the same way food is necessary for the stomach.' ${ }^{129}$

Sa'adeh was a secularist, who was strongly convinced of the necessity of the separation between religion and state. In Sa aadeh's view, Christianity (his religion by origin) had changed to be ritualistic. Contrary to early Christianity, whose followers had offered their lives for the cause of their faith, it had become one of the modern tricks in the hands of Christian states. He severely attacked religious fanaticism, but believed that religion is an integral part of the Oriental's life, and he had his strong faith that life is meant to dignify religion. ${ }^{130}$ Like Riḍā, Sa ādeh was aware of the diversity of voices and religious orientations in the Syrian homeland as well as in the Diaspora communities in South America. It was definitely not his goal to eliminate these differences. Yet he wanted to ensure that his compatriots were united at least in the defense of the national cause in order to make the Syrian voice heard within the international arena, thereby giving hope to the Syrians who had lived in despair. ${ }^{131}$

In 1906 Rị̣a briefly mentioned one of Sa 'ādeh's scientific works on pulmonary tuberculosis. ${ }^{132}$ Sa ādeh's fame as a good writer in English was primarily the reason for Riḍa to entrust him with the Arabic translation of the Barnabas Gospel. In his short biography of Sa'âdeh, Adel Beshara considered the publication of this Gospel as the most controversial event of his life. He wrote: 'the publication of

128 Ibid.

129 As quoted in ibid.

130 See the booklet in his honour, p. 29.

131 Schumann, op. cit., pp. 606-607.

132 Khalīl Sa'ādeh, al-Wiqāyah min al-Sull al-Ri'awì wā Turuq 'ilājuh, Cairo, 1906. See the review of al-Manār, vol. 9/5 (Jumāda al-'Ülā 1324/June 1906), p. 394. 
Barnabas [Beshara reads it 'Barnabus'] in Arabic was met with some scepticism largely due to religious sensitivity. The late Rashīd Riḍa inflamed the public by prefacing the work with a preamble that took its entire meaning out of context. The preamble was incorporated into the book without Sa ādeh's prior knowledge. ${ }^{.133}$ In his statement, Beshara relies on information cited by Badr Al-Hage, one of Sa ādeh's biographers, in his collection of some of the unknown works by Sa ādeh. In his account, al-Hage quoted Anțūn Sa ādeh, Khalīl's son and the later founder of the Syrian Social Nationalist Party. ${ }^{134}$ Tracing the exact source mentioned by al-Hage, I could not find the pages referred to by Anțūn. ${ }^{135}$

After the English publisher had sent him the English translation of the Gospel, Rị̂a soon settled an agreement with Sa ādeh on publishing an exact Arabic translation by his Manār. It is conceivable that Sa'ādeh must have known Ridā's reasons for publishing the Gospel. In his initial advertisement of al-Manār's plan of cooperating with Sa ādeh, Riḍa explicitly maintained that the Gospel's agreement with many Islamic principles stimulated him to think of translating it into Arabic. Besides, he was keen on making it known among Arab readers, just as the translators had done for English-speaking people. $\mathrm{He}$ also had a great desire that other translators would follow this step by increasing its publicity in all Western languages. ${ }^{136}$ One year after the appearance of the Gospel's translation, Sa ädeh contributed to al-Manār by publishing one of his scientific articles on Substance theory. ${ }^{137}$ Sa àdeh's granddaughter Sofia, presently professor at the American University in Beirut, rejects the argument that this period of her grandfather's life was controversial. In her own words: 'he was known among his contemporaries as a staunch secular person, and his translation of the Gospel was out of curiosity more than anything else. He tried also to refute the fact that it was genuine, but never

133 Adel Beshara, 'Dr. Khalil Saadeh: Nationalist Crusader,' al-Mashriq: A Quarterly Journal of Middle East studies 3/12, 2005, p. 68.

${ }_{134}$ Badr Al-Hage, Silsilat al-'A'māl al-Majhūlah: al-Duktūr Khalīl Sa'ädeh, London: Riad al-Rayyes Books, p. 17.

135 He cited Anțūn Sa'adeh, al-Athār al-Kāmilah, vol. 12, Beirut, 1984, pp. 11-15.

136 Al-Manār, vol. 10/5 (Jumādā al-'Ūlā 1325/July 1907), pp. 385-387; Riḍā expressed his gratitude to the editors for sending him a copy of this work. This copy still exists in Rị̂ā's family archive with his own signature: Milk al-Sayyid Muhammad Rashīd Rị̂̄ā (Owned by Al-Sayyid Muhammad Rashīd Rị̣ā).

137 Khalīl Sa ādeh, 'Istihāālat al-Māddah,' al-Manār, vol. 11/8, pp. 608-610. 
publicly fought with Riḍā on this specific matter even after his migration to South America.' ${ }^{138}$

Later we shall discuss Sa'ādeh's detailed evaluation of the Gospel, but it suffices here to stress that his very objective of translating the Gospel was spelled out in his introduction by saying:

'I started translating this book, which is called the Gospel of Barnabas well aware of the responsibility that I had undertaken. My aim was to serve historical studies and of course our language which is perhaps the most logical medium into which this work should be translated. This is the first time this book has come out in the Arabic language. It is a gospel about which scholars and historians have differed sharply. In these closing comments, though, I do have to stress that in this introduction all my discussions are purely scientific and historical in orientation and that I have been scrupulous to avoid all religious controversies which I left to those who are better equipped to deal with them. ${ }^{\text {'139 }}$

Even after the Gospel's publication, Sa ādeh remained in solidarity with other Syrian nationalists, including Riḍa himself (see, appendix VI). Among Riḍā's papers, I found the charter of the Ottoman Socialist Party, founded in Cairo in December 1910. The charter was signed by $\mathrm{Sa}^{\prime} \mathrm{a} d \mathrm{deh}$ as its secretary general. Among the founders of the Party were its president Shiblī Shumayyil and Rafìq al-'Azmm (1867-1925), the prominent Sunnī Muslim and the chairman of the Decentralisation Party. ${ }^{140}$ Although Riḍā's name was not included among the founders, the party's resolutions came close to his later Decentralisation Party, which demanded administrative autonomy for the Arab provinces of the Ottoman Empire. Sa'ādeh, Shumayyil and al-'Ażm shared Riḍā's political cause, and later became members of his above-mentioned Decentralisation Party. ${ }^{141}$

\subsubsection{Al-Machreq: A Jesuit Syrian Review}

Let us now turn to discuss Riḍā's polemics with the Catholic Arabic magazine al-Machreq. As the mouthpiece of the Syro-Lebanese Jesuits in Beirut since its first publication in 1898, this magazine attempted to convey for the Catholic Arab communities the value and signifi-

${ }^{138}$ E-mail to the present writer, 28 April 2005.

139 As quoted in Beshara, op. cit., pp. 68-69.

${ }^{140}$ MS, the charter of Al-Hizb al-'Uthmānī al-Ijtimā'î̀, handwritten by Khalīl Sa ādeh, Riḍā’s private archive.

${ }^{141}$ See, Hamie, 'L'homme,' pp. 101-104. 
cance of Western science and technology as well as the cultural heritage of the Near East. ${ }^{142}$ Riḍa was involved in controversies with al-Machreq around a variety of issues, especially on what he often wrote in his journal on Christianity. According to Rị̣ā's archival documents, he used to exchange the published issues of al-Manār with those of al-Machreq. The Oriental Library of the Jesuit SaintJoseph College was subscribing to his journal, and many of its issues were kept there. Despite their heated polemics, the library secretary praised Ridā's journal as having been the 'mouthpiece of the Islamic Salafī renaissance' (see, Appendix VII). ${ }^{143}$

As soon as the above-mentioned al-Manār polemicist Tāhir al-Tannīr published his anti-Christian book, Father Louis Cheikho (1859-1927), the editor of al-Machreq, fervently attacked the author. ${ }^{144}$ Tannīr's treatise, for him, was nothing but 'a childish' attempt to emulate earlier European works of 'unbelievers, Protestants, and heretics' in their critique of Christianity ${ }^{145}$ In the same year, al-Machreq accused Riḍā's journal of having 'exceeded the proper bounds by attacking the Catholic belief.' ${ }^{146}$ When al-Manār quoted an article from the Russian Muslim paper Shūrā (Council, founded in 1908) ${ }^{147}$ in which Luther had been eulogised for his reformation, the editorial of al-Machreq immediately blamed Ridā for praising him on the basis of his conflict with Catholicism. 'Had the Shürā and al-Manār known

${ }^{142}$ Al-Machreq: revue catholique orientale. See, Campbell, Robert Bell, 'The Arabic Journal, 'al-Mashriq': its Beginnings and First Twenty-Five Years under the Editorship of Père Louis Cheikho, S.j.,' unpublished $\mathrm{PhD}$ dissertation, the University of Michigan, 1972. More about Cheikho, see: Ziriklī, op. cit., vol. 5, pp. 246-247.

143 Letter, al-Machreq to Riḍ̄ā, Beirut, 2 November 1928, Riḍā's private archive.

144 Cheikho reacted with a tractate, Tafnìd al-Tazwīr li Muhammad Tāhir al-Tannīr (Refutation of the falsification of Muhammad Țāhir al-Tannīr), Beirut, 1912; as quoted in, G., 'Book Review,' The Moslem World 3/2, April 1913, pp. 197-200. See also, al-Machreq, vol. 15 (1912), pp. 432-445 \& pp. 529-543. In his answer, Cheikho also quoted Western works, such as, Laounan, Du Brahmanisme et ses rapports avec le Judaisme et le Christianisme, Paris, 1888. See also, Arthur T. Upson, 'A Glance at Al-Manār,' The Moslem World 4/4, 1914, pp. 394-395 (Quoted below, 'Glance').

${ }_{145}$ Al-Machreq, vol. 15, pp. 435-436.

146 Ibid, p. 718.

147 It was edited in Ottomanised Tatar language in the southern Uralian city of Orenburg by Rizā al-Dīn b. Fakhr al-Dīn (1859-1936). The Shūrā was much influenced by al-Manār's reformist ideas. More about the paper, its founder and the influence of al-Manār, see, Stéphane A. Dudoignon, 'Echoes to al-Manār among the Muslims of the Russian Empire: A preliminary research note on Riza al-Dīn b. Fakhr al-Dīn and the Shūrā (1908-1918), 'in Dudoignon (et al), op. cit., 2006, pp. 85-116. 
who Luther and his works precisely were,' al-Machreq wrote, 'they would have entirely discarded him and would have never contaminated their pages by mentioning his name. ${ }^{.148}$

In response to al-Manār's postulation of the doctrine of Trinity, Cheikho counterattacked Riḍa for using the Gospel of Barnabas as a weapon against it. Al-Machreq challenged Riḍa that he brought forward an Arabic translation of a 'forged' Gospel, when he lacked solid proofs against Christianity. ${ }^{149}$ Riḍā, according to him, failed to recognise the sense of the Trinity's divine mystery. Cheikho's article was specifically formulated in reaction to Riḍā's views (mentioned in the context of his response to the Danish missionary Alfred Nielsen, see, chapter 3) that: 'Muslim theologians agree that there is nothing in the Islamic faith which is logically impossible (muhâal 'aqlan), meaning that the Muslim is not required to believe in anything that is logically impossible [...] Other religions than Islam require people to believe in what is rationally impossible, i.e., the reconciliation between two antitheses or opposites, such as the real Unity and the real Trinity. In other terms, that God is truly one, and truly more than one at the same time.'

Cheikho rebuked Rị̂a for his allegation that the Catholic doctrine insists on combining contradictions. ${ }^{150}$ 'It is not logical,' Cheikho contended, 'that such a paradoxical faith would be adopted by more than one third of the inhabitants of the globe among whom are the most civilised nations-such as the Greeks, the Romans and the Arabs.' He insisted that Trinitarian concepts had been taken from the divine revelation, and Biblical prophets implicitly referred to them in the Old Testament. He pointed to many examples, such as God's use of the plural form with reference to Himself, and to the plural form for 'Lord' used frequently in the Old Testament. In his conclusion, Cheikho reminded Riḍa that Catholic believers do not entirely grasp the mystery of the Trinity. But it is enough for them to know that God revealed it to them. He further upheld that there are many secrets that cannot be interpreted by human intellect, and that it is

148 Ibid., p. 719.

149 Al-Machreq, vol. 12 (1909), pp. 558-559.

150 L. Cheikho, 'Lā Tanāquda fī al-Tawhị̄d wā al-Tathlīth,' al-Machreq, vol. 22 (1924), pp. 737-744. Among Riḍā's papers, I have found an unpublished anti-Cheikho article. It was written by a Shīi Muslim from Iraq, who signed it as Muslim Najafī under the title: 'al-Qawl al-Sahịh fị Daḥ̣ 'Ulūhiyyat al-Masīḥ (The True Saying in Refuting the Divinity of Jesus).' MS., Rị̣ā's private archive. 
impossible for human beings to grasp God's true nature; otherwise they would share with God his divine essence. ${ }^{151}$

Al-Machreq had many criticisms with regard to Riḍā's religious views of the church. For example, it suggested that his statement in one of his fatwās on polygamy that the Pope had authorised Charlemagne's polygamy was historically mistaken. As a matter of fact, although Charlemagne, who was holding power over both the Church and state, married many wives, the Catholic Church had never authorised him to do so. ${ }^{152}$ Riḍā, according to al-Machreq, insisted on writing on many subjects about which his knowledge was deficient. A prominent example was his insistence that freemasonry organisations collaborated with the Jews to demolish the Papal power in Europe. ${ }^{153}$

In 1922, one of al-Manār's readers in Beirut complained to Riḍā about the writings of al-Machreq on Islam. ${ }^{154}$ When the tenth volume of Tafsìr al-Manār was first published in 1932, al-Machreq was critical of its author's Islamic religious views. It described Rịā’s commentary on the Qur'ān as a 'naïve attempt to combine between the Qur'ān and modern scientific discoveries, which had been never known in the time of the Prophet of Islam.' ${ }^{155}$

The controversy between Riḍa and al-Machreq culminated in 1934, when the Catholic journal embarked upon reacting to his abovementioned work al-Waḥi al-Muhammadī. Al-Machreq introduced Riḍā to its readers as 'a Muslim conservative luminary in Egypt, a friend of the Wahhābī Ibn Sa ūd, and a fervent Muslim apologist, who firmly adhered to the traditions and rejected anything that is not in agreement with the way of the Salaf. ${ }^{\prime 156}$ It also depicted Riḍā's work as an attempt to idealise Islam, which did not add any new aspect of knowledge to the understanding of the concept of revelation in Islam. ${ }^{157}$

151 Ibid., p. 743.

152 Al-Machreq, vol. 5 (1927), pp. 397-398; see, Riḍā’s fatwā, al-Manār, vol. 28/1 (Sha'bān 1345/March 1917), p. 29.

153 Al-Machreq, vol. 30 (1932), pp. 143-144. See, al-Manār, 14/3 (Rabī‘ Al-'Awwal 1929/March 1911), pp. 178; vol. 15/1, pp. 32; vol. 29/4, pp. 271-72. Cf. his article on the role of the Jews in the Freemasonry movement, vol. 6/5 (Rabī' al-'Awwal 1321/ May 1903), pp. 196-200, see also, al-Manār, vol. 8/11 (Jumādā Al-'Ākhira 1323/ August 1905), pp. 401-403.

154 Al-Manār, vol. 23/4, p. 267.

155 Al-Machreq, vol. 30 (1932), pp. 237-238, cf. vol. 29 (1931), pp. 315-316.

156 Al-Machreq, vol. 31 (1933), p. 956.

157 Ibid., p. 956. 
The author's exclusive concern was to respond to Christians and verify the superiority of Islam over Christianity without giving profound treatment to any of his themes. Al-Machreq did not deny the religious value of the Qur'ān and its impact on Muslim believers in their liturgy and prayers, but this was not enough to prove its miraculous nature. ${ }^{158}$ The writer of al-Machreq was of the view that the linguistic value ascribed to the Qur'ān was no miracle in its own, and should be seen as equal to the high standard of the English or German translations of the Bible. In spite of admitting its aesthetic elements, al-Machreq alleged that there are many other linguistic and historical contradictions and defects in the Qur'ān. ${ }^{159}$ With regard to Riḍā's arguments that the Qur'annic miracle was proved by its influence and the change achieved by Islam in many parts of the world-the same argument which was earlier used by Cheikho to prove the authenticity of Catholic belief-al-Machreq viewed it as improbable. The Arabs had conquered decadent nations with ease. Muslims also learnt philosophy and other sciences from other nations, not directly from the Qur'ān. In conclusion, al-Machreq wondered why Riḍa dedicated his book to the civilised nations: 'Is it because he knows perfectly well that Islam has not gained any of the civilised nations in the modern time? Or because he knows that the majority of the more than 240 million Muslims [in the 1930s] were formerly heathens, who considered Islam civilised as compared to their previous paganism?'160

In his introduction to the book, Riḍā's stated that his work was primarily a proposal to 'call civilised countries of the West and Japan (see chapter 3) [...] and free-thinking Western scholars to Islam.' He suggested that there were three obstacles that prohibit non-Muslims from grasping the divine message of the Qur'an: 1) the Church, which opposed it by propagating a tirade of lies and accusations; therefore, its students believe every Muslim to be an enemy of Christ and Christianity; 2) Western politicians, who inherited antagonism from the Church, and accepted its fabrications in order to serve their imperialistic policy; and 3) the state of decadence among Muslims, who were blissfully ignorant of their religion. ${ }^{161}$

${ }^{158}$ Ibid., pp. 957-958.

159 For examples of these, see, ibid., pp. 958-959.

160 Ibid., p. 960.

${ }^{161}$ See the English translation, The Revelation to Muhammad, trans. by AbdusSamad Sharafuddin, Saudi Arabia, 1960. The book is also mentioned in, Fehmi Jadaane, 'Revelation et Inspiration en Islam,' Studia Islamica 26, 1967, pp. 23-47. 
On May 16, 1934, a letter from Beirut signed by a certain Cheikh \& Ladki (?) drew Riḍā's attention to Cheikho's attacks on his book. According to this letter, a group of scholars intended to react to Cheikho's critique of al-Manār. The sender of the letter (Cheikh \& Ladki) advised them to wait, since it was the author of the book who should reply (see, appendix VIII). ${ }^{162}$ Some weeks later, Riḍa started to respond to Cheikho in a series of four articles in his journal. He understood that the writer's aim to define him in such a way was to inoculate his readers with the idea that he and his journal would reject any modern religious, scientific and industrial innovations. Nonetheless, Riḍa defended himself by stating that his religious call was bound to the Qur'ann and the Sunna, while summoning Muslims to acquire all useful modern understanding in their lives, in as far as it did not contradict their religious principles. ${ }^{163}$ Riḍa was deeply frustrated by the writer's belittling of his work, blaming him for looking at it 'from behind a black-tinted Jesuit pair of glasses. ${ }^{\text {'164 }}$ On the basis of an Arabic translation of the secrets of the Jesuit order (probably made by Kirām, mentioned above, chapter 1), Riḍa judged that 'the Jesuits are more extravagant and extreme in adoring money than the Jews and capitalists. ${ }^{165}$

In his reply, Riḍa again insisted that Islam remains a 'friend' of Christianity, but not a friend of the Church. For him, Islam was also completing the 'real Christian message.' As a Muslim scholar he still regularly wished to cooperate with Christian religious bodies (especially the Vatican) to oppose atheism. ${ }^{166}$ The author of al-Machreq criticised Ridā's delineation of Islam as the religion of freedom and brotherhood as contradictory. On the one hand, he asserted that Islam gives people of other religious denominations their rights under Muslim rule, while, on the other, he strove for 'one Arab and Muslim world' by claiming that social and political reform would never be accomplished without the unity of all nations in terms of religion, language, politics and judiciary system. Riḍa asserted that human reform cannot be entirely attained without homogeneity of the vari-

\footnotetext{
162 Letter to Riḍā, Cheikh \& Ladki, Beirut, 16 May 1934, Rị̣ā’s private archive.

163 'Tafnīd I'tirāọ Kātib Jesuîtī 'alā Kitāb al-Wahī al-Muhammadī (A refutation of an objection made by a Jesuit writer to al-Wahī al-Muhammadī,' al-Manār, vol. 34/2 (Șafar 1353/June 1934), pp. 147-151.

164 Ibid., 148.

${ }^{165}$ Ibid., p. 150.

166 Al-Manār, vol. 34/3 (Rabī' al-'Awwal 1353/July 1934), pp. 227-231.
} 
ous aspects of life, even when there is no Arab nation or Muslim legislation. Riḍa insisted that Islam is the most homogenous religion capable of achieving this goal, when we compare it to other religions. The truth of Islam, he went further, does not rely on its acceptance by all human beings; and the goal of each religion is the attainment of the highest level of human perfection. ${ }^{167}$

With regard to al-Machreq's rejection of the miraculous nature of the Qur'ān, Riḍā argued that to compare the Qur'ān to English or German translations was not valid. The Qur'ān, in itself, was inimitable in its language. It had been revealed to those who were known in their age for their eloquence; while Muhammad did not belong to the category of well-known Arab poets. Islam also challenged the Arabs to produce verses similar to the Qur'ān, but they failed. On the other hand, none of the English or the German translators had ever claimed that their work was inimitable. ${ }^{168}$

Secondly, Riḍā defended the Qur'ān as the miraculous word of God by stressing again that many Western scholars agreed upon that and admitted the prophecy of Muhammad. In his book, he cited scholars such as Edouard Montet (see, chapter 1), who explained the prophetic characteristics in Islam and stressed the rationalistic essence of Islam. Riḍa moreover tried to rationalise that the prophet, without having received such a divine message, would have never been able to bring out such an 'excellent' book containing all those religious, literary and legislative sciences after having reached the age of forty. Riḍa associated the success of the Prophet's mission with the growing number of Muslims throughout history. He compared the Qur'ann to a medical guide brought forward by a physician to cure people. If he were able to cure all of his patients with the help of his guide, people would definitely believe in the soundness of his knowledge. In the same way, he went on, a huge number of non-Arabs adopted Islam because they believed in the power of its truth to guide them. As for the Arabs especially, they had adopted Islam as a result of the impact of its eloquent language on them. ${ }^{169}$

\footnotetext{
167 Ibid., pp. 227-228.

168 Al-Manār, vol. 34/4, pp. 311-315.

169 Ibid., p. 315. See also, al-Manār, vol. 34/5, pp. 376-381.
} 


\subsection{The Egyptian Coptic Community}

Some of the Egyptian Copts saw Riḍā as an intruding Syrian (dakhīl), who had no right to interfere in Egyptian affairs. ${ }^{170}$ The first one to coin the term dukhalä (intruders) for Syrians in Egypt was the founder of the Egyptian Nationalist Party Muștafā Kāmil. He advocated that the Syrians (especially Christians) were collaborators with the British and hostile to the Egyptian nationalist cause at the beginning of the twentieth century. ${ }^{171}$ In the following section we will discuss Riḍā's various reactions to the Coptic community in Egypt.

\subsubsection{Ridā's Attitudes towards the Copts before 1911}

By the late nineteenth and early twentieth century, the Coptic question and their demands for social and religious equality with Muslims had gradually become visible in the political scene of Egypt. In 1897, for example, a Coptic delegation handed a petition to the Egyptian Prime Minister and the British High Commissioner complaining that Copts were underrepresented in key political and administrative posts. ${ }^{172}$

The Copts, who viewed themselves as alienated within their own society, undertook the defence of their interests in their different newspapers and periodicals. The years 1908-1911 witnessed one of the most critical moments of the Muslim-Christian relations in the country. Muslim and Christian papers launched mutual accusations and their confrontation came to a head. The debates focused primarily

\footnotetext{
170 Al-Manār, vol. 15/1, pp. 48-49.

${ }^{171}$ For Kāmil's ideas on the concept of nationalism, see, Fritz Steppat, 'Nationalismus und Islam bei Mușțafā Kamil. Ein Beitrag zur Ideengeschichte der ägyptischen Nationalbewegung,' Die Welt des Islams 4/4, 1956, pp. 241-341. Rị̣ā was a sharp critic of Kāmil's nationalism, and was one of the early Muslim thinkers who at that moment saw the threat posed by the concept of nationalism to Islamic doctrine. About his rejection of nationalism, see, Safran, op. cit., pp. 75-84. In his turn, Kāmil declared that the Khedive himself was not pleased with Rị̣ā's stances (especially his regular critique of Al-Azhar), and had a serious plan to send him away from Egypt. See, 'Al-'Așabiyya al-Jinsiyya wā al-Liwā',' al-Manār, vol. 10/7, pp. 536-540. Riḍā defended the existence of the Syrians in Egypt, and fervently propagated the idea that the Syrians were the closest and most united faction among all emigrants to the Egyptians. See, 'Mūṣāfaḥat al-Sūriyyīn lil-Mișriyyīn,' al-Manār, vol. 11/3 (Rabī' al-'Awwal 1326/ May 1908), pp. 230-231.

${ }_{172}$ Al-Ahram Weekly, no. 691 (20-26 May 2004).
} 
on representation in civil servant employment. ${ }^{173}$ In 1908 the Coptic Reform Party, founded by Akhnūkh Fanūs, a wealthy Presbyterian Coptic landlord and member of the Legislative Assembly, had highlighted the Coptic demands as discrimination in employment and promotion, and the practice of religious rights. But other Coptic groups were anxious about their Muslim fellow-citizens. Some prominent Coptic figures accused Fanūs of collaboration with the British authorities in destroying the national spirit in their homeland. ${ }^{174}$

In the early issues of al-Manār, Riḍā's views of the Copts were positive in the general sense. He constantly praised their religious zeal and concern for education, emphasising that they were more organised than their Egyptian Muslim compatriots. He maintained that following the steps of other 'civilised lands,' the Copts set up schools to teach their children modern sciences, while keeping up their belief and religious identity. As an active class in society, they promoted proper education to the degree that it had been said that no illiteracy was to be found among them. Muslims, on the other hand, had hardly any similar organisations. ${ }^{175}$

Riḍa later developed a negative attitude as a result of what he saw as a campaign of protest against Muslims. He denounced the way the Copts presented their demands by arguing that Muslims deliberately aimed at 'rooting' them out of the country. For him, it was natural from a sociological point of view that any religious minority group would be overzealous in striving for unification in order not to be assimilated within the majority group. Being of Syrian origin, Riḍa made no distinction between any of the Egyptian minority groups including the Jews, the Copts or naturalised Orthodox Christians of Syrian or Armenian origin. He affirmed that if the Copts were serious about raising their demands of equality in the public debate, they

${ }_{173}$ Ami Ayalon, The Press in the Arab Middle East, A History, Oxford University Press, 1995, p. 61.

174 Țāriq al-Bishrī, al-Muslimūn wā al-Aqbāt fì Ițār al-Wahda al-Wațaniyya, 4th ed., Cairo: Dār al-Shurūq, 2004, pp. 79-81. Fanūs had sympathy for the British presence in Egypt. He drafted his project of establishing the Egyptian Party, which called for Egyptian-Biritsh friendship, see, id., pp. 72-73.

${ }_{175}$ See his articles, 'Al-Madāris al-Wațaniyya fī al-Diyār al-Mișriyya,' al-Manār, vol. 1/15 (S.afar 1316/July 1898), pp. 260-261. In 1898 he wrote that the Copts of Egypt as a minority group had 40 charitable schools of their own while Muslims had only one; see, al-Manār, vol. 1/21 (Rabī' al-'Awwal 1316/August 1898), pp. 388-389. See also, 'al-Muslimūn wā al-Qibț: Aw 'Ayat al-Mawt wā 'Ayat al-Hayāh,' al-Manār, vol. 8/9 (Jumāda al-'Ūlā 1323/July 1905), pp. 327-330. 
would have included other Christians in their appeal. The Copts should also stop claiming in their newspapers that Muslims were colonisers and conquerors, and had no right to be in the country. However, he also criticised those Muslims who exceeded their boundary by taking harsh stances and constantly offending Coptic religious feelings. ${ }^{176}$

The Coptic newspaper al-Wațan ('Homeland') was launched in 1877 primarily in order to provide the Coptic community with an outlet for its collective views and grievances. It soon became one of the strongest platforms for enflaming Coptic confrontation with Muslims. According to al-Manār, when the Egyptian government started the project of the revival of Arab literature in the beginning of the 20th century by reprinting famous literary works at the expense of the national budget, al-Watan vigorously attacked the project as a return to 'backwardness.' The Coptic journal criticised the Egyptian government for having embarked upon a project that would 'adulterate its people's taste for sound literatures and useful sciences. ${ }^{177}$ Instead of promoting the Egyptians to the level of civilised nations, the paper went on, the government aimed at 'thrusting them to the darkness of Arab superstitions, nonsense and ignorance. ${ }^{378}$

Riḍa was very discontent with these writings and contrasted alWattan's stance with the initiatives of European scholars and other Arab Christians (such as the Jesuits in Syria), who were keen on preserving Arab literary works by printing them. Rị̣ā counterattacked by maintaining that al-Watan's campaign aimed explicitly at 'erasing' Islam, its language and literature from Egypt and replace them with their sense of 'Coptism.' He described the Coptic writer of this article as 'fanatic,' 'rude' and 'ignorant' of Arab literature and civilisation. The Arabic language was not confined to Muslims, but was always a common ground for Jews and Christians of the Arabian Peninsula before Islam. Riḍā reminded the writer of 'fair-minded' Western thinkers (such as Le Bon and others), who admitted the significance and position of the Arabs and their language and literature in history. If the Coptic writer had been motivated to reach his conclusion by the anti-Christian statements in some of the circulating

176 'Al-Muslimūw wā al-Qibț,' vol. 11/5 (Jumādā al-'Ūlā 1326/June 1908), pp. 338-347.

177 As quoted in al-Manār, vol. 13/12 (Dhū al-Hijja 1328/January 1911), p. 909.

${ }^{178}$ Ibid. 
Arabic works, he should have not ignored the anti-Islamic tone in Arabic Christian as well as in Western missionary works. Riḍa ascribed all these remarks to al-Wațan's insistence on causing religious strife between Muslims and Copts with confidence that the British authorities would support them in their campaign. ${ }^{179}$

\subsubsection{The Coptic Congress of 1911}

Before analysing Riḍā's response to the Coptic Congress and the assassination of the Coptic Prime Minister Buțrus Ghālī, we should dwell briefly upon some parts of the historical background of the crisis and its impact on the political scene of the Egypt of 1910-1911.

During his interrogation, the afore-mentioned al-Wardānī (see, the introduction), confessed that he had murdered Ghali for his mediation between British imperial officials and Egyptian officialdom. Most Egyptian Muslim nationalists viewed Ghalī as too pliant and too willing to serve the British interests. He also represented the cabinet on the bench in the notorious Dinshiwāy trial in 1906, which resulted in the death sentences for many Egyptian farmers, the event that gave rise to the National Party of Muștafā Kāmil. ${ }^{180}$

Although al-Wardānī was sentenced to death, common Muslims held him in esteem as a national hero. During his diplomatic trip in Egypt, the former president of the United States Theodore Roosevelt fanned the flames during his speech at the Egyptian University. In that speech, he praised the British rule, condemned nationalists and vilified the assassin. ${ }^{181}$ However, al-Wardāni made it clear that although he was a Muslim and Ghālī a Coptic Christian, religion had no bearing on the motives for shooting the Prime Minister, whom he considered a traitor. ${ }^{182}$

Soon in 1911, a lay Coptic Congress was convened at Asyūt (Southern Egypt), whose main agenda was to ask for equal rights of citizenship. Asyūt was chosen because it was an important center for

179 Ibid., pp. 908-912.

${ }^{180}$ Charles D. Smith, 'The Egyptian Copts: Nationalism, Ethnicity, Definition of Identity for Religious Minority,' in Maya Shatzmiller, ed., Nationalism and Minority Identities in Islamic Societies, McGill-Queen's Press, 2005, pp. 68-69. Bishrī, op. cit., pp. 81-82. More about Ghali's life, see, for example, Muhammad Husayn Haikal, Tarājim Mișriyya wā Gharbiyya, Cairo, 1929, pp. 119-138; Arthur Goldschmidt, Biographical Dictionary of Modern Egypt, Lynne Rienner Publishers, 1999, pp. 61-62.

181 Reid, 'Cairo', pp. 51-75.

182 Badrawi, op. cit., p. 22. 
the Coptic community, a very significant centre for Protestant missionaries who also supported the idea. ${ }^{183}$ The Coptic Congress, numbering 500 members or more (Riḍa counted more than 1000), was held in spite of the opposition of Patriarch Kyrollos V and many other notable Coptic figures. They, as well as the government, feared that the Coptic meeting in Asyunt would agitate the public. The Egyptian Khedive 'Abbās Hilmì did not welcome the idea of the congress either, and refused to meet its delegation in the Palace. ${ }^{184}$

The congress, however, resulted in a petition briefing the Coptic demands before the khedive and the British. The representative of the Coptic Press in London, Kyriakos Mikhail, recorded the works of the congress and other relevant discussions. ${ }^{185}$ The congress demanded the government: 1) to exempt the Coptic government officials from their jobs and students from study on Sundays, 2) to open all administrative posts in the government services to the Copts, 3 ) to change the electoral system in the Egyptian provincial Councils to one similar to that in operation in Belgium in order to secure their rights as minorities, 4) the Copts should have equal rights to take advantage of all educational facilities provided by the new Provincial Councils; and 5) government grants should be bestowed on deserving institutions without any distinction of race or creed. ${ }^{186}$

In April 1911, Muslim Egyptians denounced the requests by organising a rival congress in Heliopolis in Cairo under the auspices of the then Prime Minister Muhammad Riyāẹ Pasha, and other politicians. The congress committee reported that the Copts were planning to establish 'a separate state for themselves. ${ }^{\text {'187 }}$ They also protested against the endeavour of the Copts 'to divide the Egyptian nation as one political unit into two religious groups, a Muslim majority and a

${ }^{183}$ Bishrī, op. cit., p. 88.

184 Ibid., pp. 86-87.

185 Mikhail, op. cit. The Coptic community was planning to hold such a congress even before the murder of Ghali, but that incident encouraged them to put it into reality. See, Bishrī, ibid., p. 82. The demands of the Congress were not different from the ones presented to Lord Cromer and Muștafā Fahmī Pasha (d. 1914), who was a strong supporter of British interests in Egypt. The Copts submitted a similar petition to Lord Cromer and Fahmī Pasha in which they requested complete equality in the appointment of administrative jobs, closing the courts on Sunday, appointing an additional member to consultative council, and teaching Christianity to Christian students in governmental schools, see, Tagher, op. cit., p. 215.

186 Mikhail, ibid., pp. 28-30.

187 Tagher, op. cit., p. 211f. More about the resolutions of the congress, see, al-Manār, vol. 14/5 (Jumādā al-'Ūlā 1329/May 1911), pp. 353-372 . 
Coptic minority.' ${ }^{188}$ It also concluded that the prime reason behind the escalation of the problem was the close relation of the Coptic organisers with Western missionary bodies in Southern Egypt, who had convinced them that the Europeans could give them protection in the event that they failed to get their demands. ${ }^{189}$

In his immediate reply, Riḍa reacted to the Coptic demands in some articles in al-Manār and al-Mu'ayyad, which he later compiled in one small volume. ${ }^{190} \mathrm{He}$ considered the Coptic congress as exercising influence in awakening Egyptian Muslims to organise their own Islamic one, and making them seriously deliberate their common social and religious affairs. He propounded to the Muslim Congress that its participants should try to avoid any discussions on politics, and to engage themselves instead of that in preparing statistical tables on the number of Coptic employees in various sectors in Egypt. ${ }^{191}$

Riḍa deplored the loss of Buṭrus Ghali as a prudent leader. Contrary to the organisers of the Coptic Congress, he was capable of defending the interests of his community in a peaceful way. Despite Ghālī's participation in the Dinshiwāy trial and his siding with the British, Riḍa enumerated many of his attributes. The most important of these was his concern for his own community, while being fair in dealing with other groups. ${ }^{192}$ Riḍa was convinced that the real motive behind his assassination was secular, not religious. Al-Wardānī made his attempt on the basis of the ideas he learnt during his stay in Europe, not at Al-Azhar or any other religious institution. The Copts, in Riḍā's view, were not satisfied with the official Muslim condemnation of the act, but intensified their accusation of Muslims as fanatics on the basis of this individual case only. ${ }^{193}$ It might be interesting to know that al-Wardānī had mixed with anarchists in Lausanne, and was influenced by their ideas. His two-year sojourn in Switzerland

188 The congress proceedings, Cairo, 1911; as quoted in ibid., p. 218.

189 Al-Manār, vol. 14/5, p. 356.

190 Riḍā, Mu'tamar.

191 Al-Manār, vol. 14/2, p. 158. Participants of the congress probably presented such statistical numbers before the congress; see, for example, the report of education in Egypt and the share of Muslims and Copts. See, al-Ta'limm fì Mișr wā Haz al-Muslimīn wā al-Aqbāț Minhū, Cairo: Mațba at al-al-Adāb wā al-Mu’ayyad, n.d. In his report, Sir Eldon Gorst also presented statistics of employment of Copts and Muslims in the Civil Service, see, Mikhail, op. cit., pp. 43-44.

192 Al-Manār, vol. 14/3 (Rabī' al-'Awwal 1329/March 1911), p. 202.

${ }^{193}$ Ibid., pp. 203-204. 
stimulated his interest in European institutions, and induced him to obtain pamphlets on different aspects of humanitarian concerns. ${ }^{194}$

In his judgement of the religious motives behind the Coptic Congress, Riḍa was cynical. He stressed that the Muslim majority would have the right to determine the weekly day off. 'If they had no desire to work on Sundays in the Muslim government of Hājj 'Abbās Hilmī [Khedive of Egypt],' Riḍā said, 'they would better relinquish their jobs and exclusively devote themselves to contemplation and prayer. ${ }^{\prime} 95 \mathrm{He}$ also refused any Coptic claim that they as original inhabitants of Egypt had the right to rule the country. The Copts were, for Riḍa, subjects to the 'Muslim Prince' of Egypt, who granted them their posts in the government services by means of tolerance, and not as a matter of obligation. ${ }^{196}$

Rị̂a, nevertheless, demonstrated that the Islamic government throughout its history contained different people with other religious beliefs, though its legislative and political principles remained decided by the majority group. He also stressed that the Islamic law gave other religious groups the right to follow their religious laws freely, without complying with Islamic rules. ${ }^{197}$

In Rịâa's thinking, 'Coptism' should remain a religious identity, and not to be mixed with any political ideologies. In other words, the Christians of Egypt should use the word 'Copt' only in addressing their religious affairs. They should only express themselves as 'Arab Egyptians.' He warned the Copts that Muslims were the majority, and they should avoid any clash with them; otherwise it would certainly end up in the loss of their rights as a minority group in case Muslims decided to boycott them. Rị̂a postulated that the Copts might have been swayed by the idea that 'Christian Europe' would interfere to force the Muslim majority to yield to their demands. In that case, Muslims would subtly try to exclude them from social life, by favouring Muslims by all means in all official posts. ${ }^{198}$

${ }^{194}$ His landlady in Lausanne would later speak of his gentleness, loyality and kindness, but he became quite agitated and upset whenever he spoke of Egypt. Another Swiss would oberserve that the youth spoke of nothing but politics, and that he did so very passionately. Bardawi, op. cit., p. 28.

${ }^{195}$ Ibid., p. 207.

196 Ibid.

197 Ibid., p. 208.

198 Ibid., pp. 211-212. In December 1930, Riḍā, as advocate of Arabism, was invited to take part in a public debate held at the Faculty of Law (the Egyptian University) on the concepts of 'Coptism' and 'Pharaonism.' His counterpart was the 
In his address to the Coptic Congress, the orator of the Coptic movement Akhnūkh Fanūs stressed that working on Sunday was a violation of the divine obligation upon Christians as 'a holy Sabbath. ${ }^{199}$ He further clarified that 'any Christian who intentionally works on Sunday should be put to death. ${ }^{200}$ As a reply to the congress' demand in this regard, Riḍa turned to expound his religious views on the 'weekly feast' in the three monotheistic religions. As compared to Riḍā's analysis, the Muslim Egyptian Congress accused the Copts of raising the issue out of 'greediness' and 'opportunism' because they had certain expectations from the 'Christian' imperial powers to assist them in removing Islamic features from the whole of society. ${ }^{201}$

Riḍa maintained that he did understand the prime significance of weekly holidays for all nations as a sign of unity, without which religious minority groups could also become weak and liable to vanish. But the national unity of each state should be given priority. He pointed out to the Coptic Congress that the Sabbath was clearly based on many passages in the Old Testament. The sanctification of Sunday, however, was not obviously established in the New Testament; and nowhere did we find in the Bible that Christ or the Apostles ordered the Sabbath to be changed from Saturday to Sunday. Riḍa referred to passages from the Old Testament relating that it was a 'perpetual covenant ... [for] the people of Israel' with regard to the day during which God rested after having completed the Creation in six days. ${ }^{202} \mathrm{He}$ insisted that Jesus did not break the Sabbath, and did not permit his disciples to break it. Riḍa quoted other New Testament passages in which it was related that Jesus allowed his followers to do a little or good activity on the holy day. ${ }^{203}$ In order to differ from the Jews, Riḍa went on, the Church replaced Saturday with Sunday, and Paul named it the Lord's Day. ${ }^{204} \mathrm{He}$ also stressed that Jewish and Muslim scriptures proving the importance of the weekly day of rest were clearer than the Christian ones. Riḍa was not concerned that minorities would follow the majority in this regard,

Egyptian lawyer Luṭîi Jum'ah. See, al-Manār, vol. 31/6 (Shábān 1349/January 1931), pp. $465-474$.

199 Bishrī, op. cit., p. 98. Riḍa connects here Sunday to the Sabbath in the Old Testament: Exodus (31:14-15) and Exodus (35:2).

${ }^{200}$ Al-Manār, vol. 31/6, p. 216.

201 Al-Manār, vol. 14/5, p. 358.

${ }^{202}$ Such as, Genesis 2:2-3, Exodus 23:12, 31:16-17, and Isaiah 56:6-8.

${ }^{203}$ Such as, Matthew 12:1-12, Mark 1:21-22, Luke 13:10-17, and John 5:1-18.

${ }^{204}$ Al-Manār, vol. 14/3, pp. 214-215. 
as was the case with Christians leaving work on Fridays under the Islamic rule, and Muslims on Sundays under the Russian Christian government. Riḍā, however, lamented that religious Christians were able to convince Muslim traders in some Islamic states to leave work on Sundays instead of Fridays. Muslims were not entirely prohibited from working on Fridays. But Riḍa argued that it was not acceptable to open government offices on Fridays, because it was highly recommended in Islam to attend the service on Friday at the mosque as early as possible. For the sake of public interest and social unity, Riḍa concluded that all religious groups in Egypt should accommodate their official schedules according to the majority in matters of labour and government office hours. ${ }^{205}$

The Coptic Congress also raised the question of equality between Muslim and Coptic children in religious education. They pleaded that all the kuttäbs (local religious schools) and the official schools should be open to all Egyptian children irrespective of their religion. The kuttābs were officially declared by the Ministry of Education to be purely Islamic institutions. The Coptic Congress requested that Coptic children should have their religious teaching within the kuttābs, just as their Muslim counterparts did. According to the Provincial Councils, none of the tax revenues were devoted to Coptic educational interests, and the children of poorer Copts were dependent for their education upon private enterprise and generosity. ${ }^{206}$

The issue of Copts partaking in religious education in primary schools had been debated in Egypt earlier. In 1907 Riḍa asserted that the Coptic demand had its religious and political aspects. From a religious point of view, accepting their demand would be also profitable for Muslims, who would be stimulated to revive their religious education parallel to that of their Christian fellows. Riḍa warned the Copts against the harm that might be caused by random attacks on the part of Muslim riot-makers in the event that the government should take any positive decision in that regard. The riot-makers would use it as a pretext to warn public opinion against what they would see as a potential plan to replace the Islamic government entirely. At that time, Riḍa however was not anxious about the introduction of Coptic religious education at primary schools, and did not

\footnotetext{
205 Ibid., pp. 218-219.

206 Mikhail, op. cit., p. 29.
} 
fear that it would lead to any kind of religious fanaticism among the members of both communities. ${ }^{207}$

In response to the Coptic Congress, Riḍa argued that it was known that there were many states which were not obliged to provide religious education to different religious groups. As it represented the majority group, the Russian state schools for instance did not teach any other religious faith, except the Orthodox doctrine. Jewish and Muslim communities had no right to give their children their own religious education in public schools. As part of the Ottoman Empire, Egyptian state schools confined their religious education only to Islam according to the Hanafi School of Law. For Riḍā, it was reasonable that the ruling majority would have the right to decide upon religious education. It was unreasonable of the Coptic Congress to appeal to the Muslim government in Egypt to change the religion of the majority. It would be unfair if the government introduced Coptic religious education in state schools, without including other religious denominations, such as all the various divisions of Judaism and Christianity. ${ }^{208}$ 'Opening the gate' of pluralism would also make the followers of the other Islamic madhāhib (schools of law) require the government to include their doctrines in religious education. ${ }^{209}$

The Copts pleaded for more rights than any other religious community, as they considered themselves to be the native population of the country. Ridā did not entirely disagree with that view. But his remark in this regard was self-contradictory. He contended that 'suppose that you [Copts] were the original descendants of the ancient Egyptians, then we [Muslims] would also have the option to follow the model of America-the most civilised Christian government in knowledge, justice and freedom-in [persecuting] native Americans. ${ }^{210}$ But he immediately renounced that by stating that the Muslim Egyptian government gave equal rights to the Copts as nationals of the country. All holders of Egyptian citizenship, Rị̣ā went on, had equal rights with no regard to their Pharaonic, Israelite, or Arab origin. However, if the Copts' allegation of being descendants from the ancient Pharaohs was true, the Jews in their progeny should be, according to Riḍā, nobler, since they descended from the line of

\footnotetext{
207 'Al-Ta 'lìm al-Dīnī', al-Manār, vol. 10/2, p. 128.

208 Al-Manār, vol. 14/3, pp. 221-222.

209 Ibid., p. 224.

210 Ibid., pp. 222-223.
} 
Prophets. But Islam did not make any differentiation between both groups regarding their religion. ${ }^{211}$

Riḍa argued that it would not have been unusual if the Egyptian government had followed the European example in stipulating one religion to be taught to all children in public schools. In Egypt, however, there were Muslim institutes, which were supported by the 'A wqā system (religious endowments) and fed by Muslims resources, donated for teaching Muslim children. Such institutes, which were run by the government, accepted both Muslim and Coptic children. These endowments, according to Riḍa, used to pay the Egyptian University five thousand pounds annually (which accepted members of both communities as well). Riḍa was convinced that although they were a minority, the Copts were more active, and their demands were merely a token of their being immoderately desirous of acquiring more power over the Muslims. ${ }^{212}$

The Coptic press attacked Riḍa for his articles about their congress. Riḍa defended himself by stating that he never thought of causing discord between the two communities. His contribution to the whole debate was purely intended for the sake of public interest. He reminded his Coptic opponents of his earlier writings in which he as, a nonEgyptian, had drawn attention to the religious and social unity and strength of the Coptic minority community in comparison with their Muslim counterparts whom he frequently accused of religious laxity. ${ }^{213}$

What troubled Riḍā was what he saw as a Coptic demand of establishing a secular system in Egypt. His reaction to this point can be seen as a new phase in his thinking. He considered their demand as a threat that would diminish the Islamic presence in Egypt. The Coptic Congress had actually softened its language by asking for equality between Muslims and Copts. ${ }^{214}$ Despite its mild tone, Riḍā still understood the Coptic plea as an attempt to replace Islam altogether with a new Coptic religious system. In line with the Muslim Egyptian Congress, he reconfirmed that the Egyptian 'Islamic' government treated the Copts with 'excessive tolerance and generosity.' Foreign powers had accused the 'fragile' Muslims of discriminating against religious minority groups. He understood that members of the Coptic

211 Ibid., pp. 223-224.

212 Ibid., pp. 225-226.

${ }^{213}$ Al-Manār, vol. 14/4, pp. 273-279.

214 Bishrī, op. cit., pp. 97-100. 
Congress not only claimed more rights for the Copts, but also pleaded for an Egyptian government which should remain Islamic. Despite the spread of non-Islamic 'illicit' acts (such as wine-drinking and adultery), Ridā defended the Egyptian government as Islamic. Islamic Law, he argued, does not consider those who commit sins as unbelievers. Although the foreign authorities did not give Egypt complete independence at that time, Rị̂a still believed that the government had not entirely lost its Islamic face. Many Islamic features characterised Egyptian society, such as the Shar ì judicial system, religious endowments, Al-Azhar's religious institutions, and religious feasts. In their demands, the Copts, Riḍa stressed, aimed indirectly at 'erasing' these Muslim aspects and replacing them with their own. ${ }^{215}$

Riḍa believed that due to their Western education Eastern Christians in general became very keen on power and authority; and had a strong desire that both Ottoman and Egyptian governments had to forsake their Islamic character altogether. He concluded that the Copts rushed to put forward their demands out of their 'hatred' against the Arabs. At the same time he referred to those whom he often called ironically 'geographic Muslim leaders,' who he had a stronger desire to remove the Islamic nature of Egypt as well. He was convinced that such a secularist group among Muslims would gradually attain the same aim by weeding out Islamic elements in their opposition to any Islamic initiative in the society. Riḍa again warned the Copts that they should remain content with the rights they had already been given enabling them to reach high official positions in Egypt. He further notified the Copts that their demands would agitate the Muslim public feelings against them, if their wishes to replace the Muslim character of the government were to be put into practice. The Supreme Porte might also take strict measures to retain its Islamic state. It would also widen the gap of understanding between Islam and Christianity in other Muslim lands, since Egypt was seen as one of the pivotal centres of Islam. The British officials, as a result, would try to quell any discontent among Muslims in their colonies (especially India) by opposing the Coptic plans. The Copts, Riḍa argued, would in this way harm their status and lose some of their rights instead of gaining any. ${ }^{216}$

${ }_{215}$ Al-Manār, vol. 14/4, pp. 279-284.

${ }^{216}$ Ibid., pp. 285-287. 
Although he did not take part in its activities, Ridā stood firmly behind the Muslim Egyptian Congress. It was, in his view, effective, but belated. The first fruitful consequence was the change of tone in the Coptic protest. He believed that the Copts adopted a milder tone in presenting their requests after they saw that the Muslim majority were attempting to recover their unity. He compared the situation in Egypt with India. Muslims of India had recognised the importance of their unity by holding their annual meetings and congresses, when they saw the Hindus trying to promote their social unity. The same held true for Egyptian Muslims who through this congress achieved a remarkable progress in the direction of their unity. The dependency of Muslim Egyptians on their government in regulating their affairs was, in Riḍa's view, the reason they had been tardy in achieving integrity and unity. Following al-Afghānī's political ideas, Riḍā strongly believed that any governmental reform could not be established without the reform of the state as a whole. The leaders of any state should also exert many of their efforts and the natural resources of their countries in serving their subjects, preventing their people from any unneeded involvement in politics. Politics, as well as religious, economical and social public affairs should be run by a group of experts whom the people trust. Riḍa related the success of Western societies to their careful concern to promote talented people in various fields and giving them leadership in offices and institutions. He was therefore satisfied with the decision of the Muslim Egyptian Congress not to interfere in any political discussion or conflict, and to concentrate on investigating the Coptic demands only, and on collecting facts and statistics about Coptic and Muslim officials in various offices. He again warned the Copts to stop accusing Muslims of stirring up religious fanaticism and to make an end to their writings in such a 'despising' language in their press. ${ }^{217}$

Riḍa concluded by recommending that the Muslim Egyptian Congress should regulate religious and social Islamic affairs. His proposal was general and did not include any suggestion directly related to the Coptic question. He prompted its members to have its center in Cairo and establish five permanent committees: 1) an administrative committee to regulate all further work; 2) a committee for education, which would organise charitable educational institutes and

217 Ibid., pp. 288-291. 
schools, and would in the future make a plan for establishing an Islamic college for girls; 3 ) a committee for preaching and guidance (al-Wa'zwa al-'Irshād), which would be entrusted to supervise preachers who would be sent all over the country; 4) an economic and financial committee, which would take care of investigating the matter of giving loans to poor families and combating usury and non-Islamic financial transactions; and 5) a charitable committee, which would provide assistance for aged, orphans and needy people. ${ }^{218}$

\subsubsection{Salāma Mūsā}

Even after his sharp critique of the Coptic Congress, Riḍa still admitted its success in strengthening to the social and ethnical bond among the Copts. At the same time, he constantly accused 'Coptic Egyptianists' of attacking al-Manār as a platform for Islamic ideas. Some of the Coptic newspapers also heavily criticised Riḍa for his anti-Christian writings.

Riḍa took part in polemics against the Coptic intellectual Salāma Mūsā (1887-1958) for his writings on Islam and religions in general. It is worth noting that Mūsā was the foremost disciple of the Syrian intelligentsia in Egypt. By the 1920s, when the zenith of the Syrian Christians in Egypt started to be on the wane (Zaidān died in 1914, Shumayyil in 1917, Anțūn in 1922, and Șarrūf in 1927), Mūsā adopted without any hesitation the secularism of Syrian Christians. His readings in their works had clearly moulded his ideas on various subjects. Unlike his Syrian mentors, Mūsā was blunt and straightforward in his critique of Islam. Zaidān once advised him to omit a few offending paragraphs in one of his articles on Islam. 'Never mind,' said Zaidān, 'if we criticise the Christians, for they themselves have already written the critique of their religion [Christianity]. But we must treat Muslims with circumspection. They have not yet produced any selfcriticism. ${ }^{219}$ Mūsā developed his philosophy of 'Egyptianism,' and advocated the idea of liberating society from what he deemed as shackles of theological traditions. Unlike the sense of 'Arabness' we have noted among Syrian Christians, Mūsā argued that Arabic should

${ }^{218}$ Ibid., pp. 295-298.

219 Salama Musa, Tarbiyat Salāma Mūsā, Cairo, 1947, p. 185; English Translation, The Education of Salama Musa, Leiden: E.J. Brill, 1961, p. 153. 
be 'declassicised' for the sake of Egypt. He encouraged therefore the idea of promoting the Egyptian dialect in literary works. ${ }^{220}$

In 1912 Salāma Mūsā published his Arabic translation of the treatise of the famous British writer Grant Allen (1848-99), The Evolution of the Idea of God. ${ }^{221}$ Throughout his work, Allen tried to demonstrate that theology is a product of the human mind, and Christianity is riddled with pagan traditions. Two years later, Riḍa reviewed the book by stating that such attacks of modern atheists on religion have no impact on the conception of monotheism in Islam. Such European writers, he argued, became very critical of Christianity once they observed its 'pagan' elements. ${ }^{22}$ Consequently, the Coptic newspaper Mișr ('Egypt,' firstly published 1895) launched a campaign against Riḍa for his assault on Christianity as a pagan religion. The paper appealed to the Egyptian government to ban Rị̣ā's journal and banish him from Egypt for causing religious strife among Muslims and Copts. Husayn Rushdī (1863-1928), the then Prime Minister, invited Rị̣a to his house to discuss the matter. ${ }^{223}$ Riḍa explained to him that he had published a review of the book just as many other Egyptian papers had done. He also elucidated that his intention was to defend Islam against missionary writings by using such critical writings in his counterattack. He adamantly added that his journal would continue its anti-missionary campaign as long as they continued to publish their attacks on Islam. Rushdī requested Riḍa to confine his writings to defence only. Riḍa expressed his readiness to prepare a long list of anti-Islamic citations in missionary literature. He also tried to convince the Prime Minister that the Coptic daily was seeking the support of British missionaries in order to close down his journal and his preaching of Islam in Cairo. ${ }^{224}$

According to Riḍā, the anti-Manār campaign was led by Yùsuf al-Khāzin (died in Italy, 1944), a Christian Syrian editor in Cairo. He

${ }^{220}$ More about him, see, Sylvia G. Haim, 'Salama Musa, An Appreciation of his Autobiography,' Die Welt des Islams 2/1, 1952, pp. 10-24, Ibrahim A. Ibrahim, 'Salama Musa: An Essay on Cultural Alienation,' Middle Eastern Studies 15, 1979, pp. 346- 357, Vernon Egger, A Fabian in Egypt: Salamah Musa and the Rise of the Professional Classes in Egypt, 1909-1939, University Press of America, 1986.

${ }^{221}$ Grant Allen, The Evolution of the Idea of God, London, 1903.

${ }^{222}$ See, al-Manār, vol. 17/3, pp. 225-231.

${ }^{223}$ Al-Manār, 'Muhārabat Muta așșibī al-Qibț wā Ghayrihim lil-Manār (The Fanatic Copts [...] Combating al-Manār),' vol. 17/6 (Jumādā al-'Ākhira 1332/May 1914), pp. 487-490.

${ }^{224}$ Ibid., p. 479. 
was a member of the staff editorial of the above-mentioned Coptic newspaper al-Wațan. ${ }^{225}$ Riḍa accused him of being one of the most fanatic Christians. According to al-Manār, al-Khāzin was reported to have said that he 'felt uncomfortable when a Muslim would greet him. ${ }^{226}$ Riḍa again claimed that his opponents made another attempt to request the British Commissioner and the Egyptian government to imprison or banish him from Egypt, but that their campaign was not successful. He moreover stressed that people knew the objective of his journal from its early beginning; it never intended to propagate any religious strife or animosity against Christians. ${ }^{227}$

In Ridâa's view, worse than missionaries were those westernised Muslims and Christians. He deemed that Salāma Mūsā, born a Christian, was one of the strongest propagators of 'atheism' and 'absolute looseness,' who certainly endangered the Egyptian nation through his contributions in al-Hila $\bar{l},{ }^{228}$ in which he became the principal writer and a leading pundit by the 1920s. He had also published nine books since he had joined the staff of its company. ${ }^{229}$ Riḍa became upset that Emile Zaidān, the subsequent editor of al-Hilāl, gave Mūsā this opportunity of attacking religion, and did not follow the line of his father who was more mindful of religions, their values and the entity of the Arab nation. Rị̣a saw Mūsā's books published by al-Hilāl as a 'destructive propaganda against any oriental nation, which might be dazzled by his subverting materialistic philosophy. ${ }^{230} \mathrm{On}$ its part, Mūsā's own magazine al-Majalla al-Jadìda accused Riḍa of accumulating huge wealth through the distribution of his journal in which he offended Muslim thinkers by constantly charging them with infidelity. ${ }^{231}$

Riḍa was one of the founding members of the above-mentioned Jam iyyat al-Rābița al-Sharqiyya (Association of Oriental League, established 1921-1922). ${ }^{232}$ When the mouthpiece of the association,

${ }^{225}$ In Cairo, he founded other journals al-Akhbār (1896), al-Khizāna (1900), and al-Ahad. Later he became a member of the Parliament in Lebanon. See, Zirklī, op. cit., vol. 8, p. 228.

226 'Al-Ta așșub 'alā al-Manār,' al-Manār, vol. 17/4, p. 17.

227 Ibid., pp. 318-319.

${ }^{228}$ Al-Manār, vol. 29/2 (Shawwāl 1346/April, 1928), p. 118.

229 Egger, op. cit., p. 169.

${ }^{230}$ Al-Manär, 29/2, p. 118.

231 Al-Majalla al-Jadida, vol. 2/10 (August 1931), p. 1180.

${ }^{232}$ The Association of the Oriental League was Egypt's Asian affiliation. It aimed at disseminating the arts, literatures and sciences of the Orient, strengthening rela- 
Majallat al-Rābița al-Sharqiyya, first appeared in 1928, its editorial included the controversial modernist 'Alī 'Abd al-Rāziq, and several of its contributors were leading Egyptian liberals, including Salāma Mūsā. Mūsā openly proclaimed his 'disbelief in the East and 'faith' in the West. His 'anti-Easternism' caused controversy and he was criticised for his assertions that Egypt was historically part of the Western rather than the Eastern world and that even the ethnographic and linguistic roots of Egypt were closer to the peoples of Europe as opposed to those of Asia. ${ }^{233}$

Ridā immediately attacked the association for its drift towards 'spreading atheist culture' by publishing the views of such liberals in its magazine. ${ }^{234} \mathrm{He}$ was disappointed that the association, which had earlier gained his support, had now given an opportunity to Mūsā as 'propagator of unbelief and impudence' and an 'enemy of religions in general and Islam in particular, of morality and spiritual values, and of any Eastern nationalist, ethnical or linguistic bond. ${ }^{235}$ Riḍā was concerned at Mūsā's demands for a 'westernised' Egyptian society, and the excessive praise in his writings of the British as an attempt to convince his readers of the necessity of 'assimilating Muslims into the English nation. ${ }^{236}$ For him, the westernisation of Muslims would only be achieved at the expense of Islamic traditions and values. The present Christianity and its doctrine of the Trinity, for Ridā, were far removed from the authentic message of Jesus, which was only to be found in the Gospel of John: 'Now this is eternal life: that they may

tionships between countries of the region and acquainting Egypt with that part of the world, regardless of race and religion. More about the association, see, J. Jankowski 'The Eastern Idea and the Eastern Union in Interwar Egypt,' The International Journal of African Historical Studies 14/4, 1981, pp. 643-666. More about Riḍā's activities in the association, see al-Manār, vol. 23/3 (Rajab 1340/March 1922), pp. 219-223. In Ridā archive, there are copies of the charter of the association and some reports of its gatherings besides some remaining letters addressed to him by its chairman Ahmad Shafíq Pasha.

${ }^{233}$ Ibid., p. 645. More in Egger, op. cit., pp. 124-132.

${ }^{234}$ Ibid., p. 660. Riḍā's major opponent in the League was 'Alī 'Abd al-Rāziq, the author of the well-known book al-'Islām wà Ușūl al-Hukm, who was also appointed as the editor of the magazine. The tension between al-Manār and the League's magazine escalated, and both sides exchanged insults. Amīn al-Husaynī, the mufti of Jerusalem, had to interfere to reconcile between both sides. See, al-Manār, vol. 29/10 (Shawwāl 1347/April 1929), p. 788-791

${ }^{235}$ Al-Manār, vol. 29/8 (Jumādā Al-'Ākhira 1347/December 1928), p. 620.

${ }^{236}$ Ibid., p. 623; Mūsā described the English as 'the greatest nation on earth,' their government is the most advanced, England surpasses all other countries, the English are unsurpassed in quality of character. See Egger, op. cit., pp. 126-127. 
know You, the Only True God, and Jesus Christ, whom You have sent' $(3: 17)$.

In the 1930s Ridā became involved in public discussions about Egypt's religious and national identity. A well attended debate over the issue of whether Egypt's culture was 'Pharaonic' or 'Arab' was held at the Faculty of Law of the Egyptian University in December 1930. In this debate Riḍa claimed the massive and decisive Arab and Islamic character of Egypt, while his counterpart the Egyptian lawyer, Muhammad Luțī Jum'ah, defended the uniqueness of Egyptian culture. ${ }^{237}$ Mùsā advocated the Pharaonic identity of Egypt as well, which he considered as superior to the Arab-Islamic heritage both by virtue of its more ancient age and its remarkable achievements. ${ }^{238}$ In his debates on the 'Arabness' of the Egyptian culture, Riḍa frequently ridiculed Mūsā for his backing of the concept of Pharaonism. What irritated Rị̂ā was Mūsā's giving precedence to the ancient Egyptian culture above the Shari'a besides what he understood as 'insults' and 'offences' against anyone who would advocate Islam and its establishments in Egypt. He was very saddened by Mūsā's depiction of Shakīb Arslān as 'villain' (waghd). Rị̣ā also felt very offended and tried to prove his Egyptian nationality, when Mūsā personally debunked him as a non-Egyptian, who had no right to interfere in such Egyptian affairs. Mūsā now reminded his readers of Riḍā's part in the 'AbduhAnțūn debate by pointing out that al-Manār had assassinated al-Jämi ${ }^{\prime}$. By this the Egyptian youth had thus lost one of the significant intellectual sources in the country. In his words, Mūsā commented: 'we [Egyptians] should understand our duty [...] the Egyptian press should remain an Egyptian craft, not only with its Egyptian public readers, but also with its craftsmen and editors, who must also remain Egyptian. ${ }^{239}$

Riḍa related Mūsā's views on Islam to his 'ignorance' and 'animosity.' An example was his critique of the inequality between men and women in the inheritance law. Riḍa believed that the reason behind Mūsā's criticism was his ambition to replace Eastern identity with Western models of life and style of dress. Again Riḍā was disappointed that the mouthpiece of the Oriental League had given Mūsā the chance

${ }^{237}$ Israel Gershoni and James P. Jankowski, Redefining the Egyptian Nation, 19301945, Cambridge University Press, 1995, p. 28.

${ }^{238}$ Egger, op. cit., pp. 136-139.

239 As quoted in al-Manār, vol. 32/1 (Jumādā al-'Ākhira 1350/October 1931), p. 59. 
to spread his ideas. Unlikely, the famous Egyptian feminist Hudā Sha'rāwī (1879-1947), according to Rị̣ā, had once rejected a request put forward to her and her feminist society by Mūsā in which he appealed to the Egyptian government for the equality of inheritance law. She rejected his request because she was convinced that any plan to reform the social standards of women should emanate from Islamic Law itself. ${ }^{240}$

Riḍa took up the issue of women's inheritance law once again in a lecture which he delivered at the Egyptian University. ${ }^{241}$ He attacked Mūsā again, suggesting that the overriding reason for his hatred against the Arabs was that they had conquered his land and had changed it into a Muslim state. He added that he would probably have preferred that Egypt should have remained a part of the Christian Roman Empire despite their persecution of his Coptic people for many years. Looking at Mūsā's own writings, we find that although he gave priority to the Pharaonic culture, he did not deny the social impact of Arabs and Islam on the Egyptians. He believed that the Arab conquest of Egypt had brought a new era of civilisation, and that Islam had unfettered its people from sectarian disputes and the Roman political and economical exploitation. ${ }^{242}$

In addition to his propagation of atheism, Riḍa continued, Mūsā in his animosity spared no effort to drive Muslims away from their religion. Some Muslim 'atheists' rallied behind him under the slogan of tajdìd (renewal). Rị̣a referred to one of the lectures delivered by Mūsā in 1928 to the members of the Association of Christian Young Men (A.C.Y.M.). In this he held that the status of women in Islam was inferior, especially in its stipulation of inheritance. Riḍa maintained that Mūsā was the first writer to raise these allegations. The Egyptian Constitutionalist Mahmūd 'Azmì and the Coptic-Catholic Faraj Mikhāill delivered a similar lecture on the same subject. The three of them, Riḍa believed, brought forward the issue of women's inheritance not because they were concerned with removing inequality

${ }^{240}$ Al-Manār, vol. 29/8, p. 624.

${ }^{241}$ Al-Manār, vol. 30/9 (Dhū al-Qi'da 1348/April 1930), pp. 690- 709.

${ }^{242}$ See, for instance, Ghālī Shukrī, Salāma Mūsā wā Azmat al-Damīr al-'Arabì, Beirut, 4th edition, 1983, p. 137. Mūsā admitted the tolerance of Islam given to other religious groups, and attributed the negative behaviour to some Muslim rulers, id., p. 219. 
between men and women, but by raising such discussions they aimed at causing the umma to disintegrate. ${ }^{243}$

\subsection{Conclusion}

In order to evaluate Riḍā's attitudes towards the Arab Christians of his age, we have analysed various cases. Syrian Christian émigrés in Egypt, who had lively relations with him, were mostly drawn to the world of journalism and political activism. We have observed how complex his approaches were towards them as secularists: sometimes they were on friendly terms, but he sometimes tended to have religious and intellectual controversies and heated polemics with some others as well. His positive or negative postures were mostly determined by his counterpart's stances towards the concepts which he adamantly espoused in his writings, especially those related to Islamism or Arabism. He was therefore pragmatic in his political co-operation with them, and ready to co-operate with many of them as long as they accepted the Islamic character of society. Ridā's critique was coupled with an assault on those whom he called 'geographic Muslims,' who were also trying to weed out Islamic elements from society. I would venture to say that the rejection by Arab Christians of many Christian fundamentals and their sharp criticism of Christian clergymen were likely to be among the prime motives behind his willingness to cooperate with them. $\mathrm{He}$, on the other hand, was not willing to tolerate the Jesuit attack on Islam and Mūsā's critique of Islam.

Ridā's stance towards the Coptic community was more sensitive. Some Copts considered him a non-Egyptian 'intruder,' who had no right to interfere in Egyptian affairs. In its response to the Coptic Congress, al-Manār did not attempt to analyse in depth the drastic impact of al-Wardānī's assassination of Buțrus Ghālī on the longstanding and sensitive relation between Muslims and Copts. Riḍā's position was more apologetic towards their demands. He did not take the issue further than discussing the status of non-Muslim minorities under Islamic rule, and accussing some Coptic groups of inflaming the religious strife among different communities. His tone was sometimes cynical. This was clearly shown when he cautioned the

${ }^{243}$ Al-Manār, vol. 30/9, p. 700. 
Copts to be 'satisfied' with the rule of the Khedive 'Hāijj Abbās.' Throughout his articles, Rị̣ā neither severely condemned Wardānī's crime, nor extolled his act. He was also silent on the religious discourse prevalent among Muslim scholars (who did not condemn his act) and some other nationalist groups (who hailed al-Wardānī as a national hero). ${ }^{244}$

${ }^{244}$ The then mufti of Egypt, for example, did not support the verdict of the Egyptian court by considering imposing the death penalty on al-Wardāni as unjustified from his own religious point of view. See, Badrawi, op. cit., p. 41. 
U. Ryad - 9789047441465

Downloaded from Brill.comఠ4/26/2023 04:40:22AM via free access 